\title{
Characterization of zinc amino acid complexes for zinc delivery in vitro using Caco-2 cells and enterocytes from hiPSC
}

\author{
Ann Katrin Sauer - Stefanie Pfaender - Simone Hagmeyer $\cdot$ Laura Tarana • \\ Ann-Kathrin Mattes · Franziska Briel · Sébastien Küry • Tobias M. Boeckers • \\ Andreas M. Grabrucker (D)
}

Received: 24 February 2017 / Accepted: 6 July 2017 / Published online: 17 July 2017

(C) The Author(s) 2017. This article is an open access publication

\begin{abstract}
Zn}$ is essential for growth and development. The bioavailability of $\mathrm{Zn}$ is affected by several factors such as other food components. It is therefore of interest, to understand uptake mechanisms of $\mathrm{Zn}$ delivering compounds to identify ways to bypass the inhibitory effects of these factors. Here, we studied the effect of $\mathrm{Zn}$ amino acid conjugates (ZnAAs) on the bioavailabilty of $\mathrm{Zn}$. We used Caco-2 cells and enterocytes differentiated from human induced pluripotent stem cells from a control and Acrodermatitis enteropathica $(A E)$ patient, and performed
\end{abstract}

Electronic supplementary material The online version of this article (doi:10.1007/s10534-017-0033-y) contains supplementary material, which is available to authorized users.

A. K. Sauer · S. Hagmeyer · A. M. Grabrucker $(\square)$ WG Cellular Neurobiology and Neuro-Nanotechnology, Department of Biological Sciences, University of Limerick, Limerick, Ireland e-mail: andreas.grabrucker@ul.ie

A. K. Sauer · S. Hagmeyer · A. M. Grabrucker Bernal Institute, University of Limerick, Limerick, Ireland

A. K. Sauer - S. Pfaender - S. Hagmeyer ·

L. Tarana $\cdot$ A.-K. Mattes $\cdot$ F. Briel ·

T. M. Boeckers - A. M. Grabrucker Institute for Anatomy and Cell Biology, Ulm University, Ulm, Germany

S. Küry

CHU Nantes, Service de Génétique Médicale, Nantes, France fluorescence based assays, protein biochemistry and atomic absorption spectrometry to characterize cellular uptake and absorption of ZnAAs. The results show that ZnAAs are taken up by AA transporters, leading to an intracellular enrichment of $\mathrm{Zn}$ mostly uninhibited by $\mathrm{Zn}$ uptake antagonists. Enterocytes from $A E$ patients were unable to gain significant $\mathrm{Zn}$ through exposure to $\mathrm{ZnCl}_{2}$ but did not show differences with respect to ZnAAs. We conclude that ZnAAs may possess an advantage over classical $\mathrm{Zn}$ supplements such as $\mathrm{Zn}$ salts, as they may be able to increase bioavailability of $\mathrm{Zn}$, and may be more efficient in patients with $A E$.

Keywords Zip4 - Acrodermatitis enteropathica . Absorption · Gastro-intestinal · Enterocyte $\cdot$ hIPSC

\section{Introduction}

Research from the last decades clearly shows that $\mathrm{Zn}$ has a vital role in neonatal and postnatal development, and adult life. $\mathrm{Zn}$ is an essential trace element in humans and animals, and is involved in countless metabolic and signaling pathways within the body. However, a particular role of $\mathrm{Zn}$ in the immune system and brain has been reported (Prasad 2014).

Two major pools of $\mathrm{Zn}$ can be found within the body. One pool that contains about $90 \%$ of the body's $\mathrm{Zn}$ is exchanging $\mathrm{Zn}$ slowly with the blood. The second pool that rapidly exchanges $\mathrm{Zn}$ with the plasma 
contains the other $10 \%$ of $\mathrm{Zn}$ and is the one that is especially reactive to the amount of absorbed $\mathrm{Zn}$ from the diet (Hambidge et al. 1986). This $\mathrm{Zn}$ supply is dependent on the amount and bioavailability of $\mathrm{Zn}$. In a western mixed diet consisting of commonly consumed foods, the bioavailability of $\mathrm{Zn}$ is about 20-30\% (Gallaher et al. 1998). Various compounds and substances present in the diet can inhibit $\mathrm{Zn}$ absorption. For example, phytates such as inositol hexaphosphates and pentaphosphates bind to $\mathrm{Zn}$ and reduce its availability (Lönnerdal 2000; King 2007). Further, high fructose corn syrup (HFCS) is able to influence $\mathrm{Zn}$ absorption, as does $\mathrm{Cu}$, which has an antagonistic relationship with $\mathrm{Zn}$ (Hill and Matrone 1970; Mills 1985; Hall et al. 1979; Huster 2010). Moreover, $\mathrm{Ca}$ and $\mathrm{Fe}$ might interfere with the absorption of Zn (Wood and Zheng 1997; Whiting and Wood 1997; Argiratos and Samman 1994; O’Brien et al. 2000; Fischer Walker et al. 2005; Hambidge et al. 1983). Additionally, folic acid, a nutrient commonly prescribed and supplied at higher levels during pregnancy has been shown to decrease $\mathrm{Zn}$ absorption (Ghishan et al. 1986; Simmer et al. 1987; Krebs 2000).

Regarding $\mathrm{Zn}$ in supplements, the bioavailability can vary from very low (e.g. zinc oxide) to comparatively high (e.g. zinc salts such as zinc acetate) and is influenced by multiple factors (competition with other minerals as well as $\mathrm{Zn}$ itself supplied through dietary sources, inhibition by food substances) (Lönnerdal et al. 1984). An ideal Zn supplier should therefore use other routes as those potentially inhibited and saturated by $\mathrm{Zn}$ and other competitive trace metals, such as classical Zn transporters.

Here, we investigated uptake and absorption of three compounds with $\mathrm{Zn}$ bound to amino acids (ZnAAs): Zn-glutamate (ZnGlu), Zn-lysine (ZnLys) and $\mathrm{Zn}$-methionine (ZnMet). ZnAAs have been studied in the past. For example, it was shown that $100 \mathrm{ppm} \mathrm{Zn}$ from ZnAAs additional to $100 \mathrm{ppm} \mathrm{Zn}$ from $\mathrm{ZnSO}_{4}$ in sow diets may increase pigs born and weaned per litter (Payne et al. 2006), and that ZnMet supplemented diet slightly improves intestinal morphology of weaned pigs (Metzler-Zebeli et al. 2010). Further, ZnAAs showed positive effects regarding production parameters in dairy cows (Osorio et al. 2016; Nayeri et al. 2014), and a higher bioavailability of $\mathrm{Zn}$ from $\mathrm{ZnAA}$ compared to $\mathrm{Zn}$ from $\mathrm{ZnSO}_{4}$ was shown in broilers (Star et al. 2012). However, the different possible routes of uptake of these ZnAAs have not been investigated in detail so far.

Under physiological conditions, $\mathrm{Zn}$ is taken up in the gastrointestinal (GI) tract into enterocytes by $\mathrm{Zn}$ transporters of the Zrt- and Irt-like protein (ZIP/ SLC39A) family that mediate the uptake, while $\mathrm{Zn}$ transporters of the Zinc Transporter (ZnT/SLC30A) family mostly mediate removal. For example, the ZIP4 (SLC39A4) transporter plays a major role in $\mathrm{Zn}$ absorption in the small intestine (Cousins and McMahon 2000). Mutations in ZIP4 may cause Acrodermatitis enteropathica $(A E)$, a rare and, if left untreated, lethal autosomal recessive genetic disorder of $\mathrm{Zn}$ uptake (Andrews 2008). The release of $\mathrm{Zn}$ from enterocytes into the blood stream, in turn, is mediated by ZnT1 (SLC30A1) (Cousins 2010).

Amino acids, for example from digested proteins, are taken up by at least four sodium-dependent amino acid transporters, and sodium-independent transporters, mediating the uptake of acidic, basic, neutral amino acids. We investigate $\mathrm{Zn}$ bound to glutamate (Glu), lysine (Lys) and methionine (Met). Glu is a nonessential AA and classified as acidic AA. L-Lysine ( $\alpha, \varepsilon$-diaminocarpoic acid) and L-Methionine (2amino-4-(methylthio)butanoic acid) are essential AAs. Lys is a basic AA, whereas Met belongs to the hydrophobic AAs.

As in vitro model for $\mathrm{Zn}$ uptake and absorption, we use the human intestinal cell line Caco-2. Caco-2 cells have been used to assess $\mathrm{Zn}$ metabolism previously (Zödl et al. 2003) and are recognized by the FDA as a validated model to study drug absorption in humans (Corti et al. 2006). In addition, we use human enterocytes differentiated from a healthy individual and a patient with $A E$. For in vivo studies, we use mouse models that were fed different diets containing antagonists with and without ZnAAs for 8 weeks. The $\mathrm{Zn}$ transporters in the intestines of mice and humans are highly conserved not only in their sequence but also the different isoforms. We hypothesized that $\mathrm{Zn}$ linked to AAs might be taken up by AA transporters to some extent and thus may ameliorate inhibition of $\mathrm{Zn}$ absorption in the presence of antagonists. 


\section{Results}

Zn deficiency can be induced by uptake antagonists in vivo

Rather than the total concentration, the bioavailability of $\mathrm{Zn}$ in the diet plays a major role for the $\mathrm{Zn}$ status of the body. As a proof of principle, we fed female wild type C57BL/6 mice 3 different diets for 9 weeks. The diet was started in 10 weeks old animals. Diet 1 (Control) was a standard laboratory diet containing all necessary vitamins and minerals including $41 \mathrm{mg} / \mathrm{kg}$ $\mathrm{Zn}, 0.72 \% \mathrm{Ca}, 113 \mathrm{mg} / \mathrm{kg} \mathrm{Fe}, 4.5 \mathrm{mg} / \mathrm{kg}$ phytates, and $0.7 \mathrm{mg} / \mathrm{kg}$ folic acid. Diet 2 ( $\mathrm{Zn}$ deficient) was the same standard laboratory diet except $\mathrm{Zn}$ was reduced to $19 \mathrm{mg} / \mathrm{kg}$. Diet 3 ( $\mathrm{Zn}$ inhibitor) was a standard laboratory diet containing the $41 \mathrm{mg} / \mathrm{kg} \mathrm{Zn}$, but with increased levels of $\mathrm{Zn}$ uptake antagonists $(1.13 \% \mathrm{Ca}$, $503 \mathrm{mg} / \mathrm{kg} \mathrm{Fe}, 9.5 \mathrm{mg} / \mathrm{kg}$ phytates, and $1.9 \mathrm{mg} / \mathrm{kg}$ folic acid). A complete list of ingredients can be found as supplementary data (Supplementary Data 1).

Whole-blood $\mathrm{Zn}$ levels were investigated by AAS in three animals per group (Fig. 1a). The results show that animals on a $\mathrm{Zn}$ deficient diet (Diet 2) had significantly reduced $\mathrm{Zn}$ levels compared to mice on the control diet (Diet 1) (one-way ANOVA, $\mathrm{F}=8.740, p=0.017$, Post hoc analysis: Control vs. Zinc deficient, $p=0.0461$ ). Interestingly, mice on the control diet that contained increased levels of $\mathrm{Zn}$ uptake antagonists (Diet 3) showed a reduction in blood-zinc levels similar to the mice on the $\mathrm{Zn}$ deficient diet (Control vs. Zinc inhibitor, $p=0.0307$ ). Thus, despite adequate supply of $\mathrm{Zn}$ in the diet, the presence of increased levels of $\mathrm{Zn}$ uptake antagonists was sufficient to induce $\mathrm{Zn}$ deficiency in mice. To overcome the antagonistic effects and thus to increase bioavailability of Zn, delivery of Zn using ZnAAs may be a promising approach.

$\mathrm{Zn}$ from ZnAAs is taken up by AA transporters in Caco-2 cells

In the $\mathrm{ZnAAs}$ used in this study, the complex with $\mathrm{Zn}$ is formed between the amino acid group and the alpha nitrogen. Thus, although the side group may increase the stability, it is not needed for binding. In a first set of experiments, we investigated the possibility to visualize ZnAA complexes in cell free conditions by fluorescent probes. To that end, we used Zinpyr1, a Zn fluorophore that is able to bind to $\mathrm{Zn}$ found in complex with an AA (Fig. S1b). To investigate $\mathrm{Zn}$ uptake from ZnAA in vitro, and to characterize the uptake pathways, we used the human intestinal cell line Caco-2 since the intestine is the first tissue confronted with large quantities of $\mathrm{Zn}$. Caco-2 cells were incubated for $30 \mathrm{~min}$ with $\mathrm{ZnCl}_{2}$ solution $(50 \mu \mathrm{M})$ or ZnAAs delivering an equivalent of $50 \mu \mathrm{M} \mathrm{Zn}$. The mean intracellular $\mathrm{Zn}$ concentration per cell was determined by Zinpyr-1 fluorescence intensity. Zinpyr-1 is a membrane-permeant fluorescent sensor for $\mathrm{Zn}$ with a high specificity and affinity $(\mathrm{Kd}=$ $0.7 \pm 0.1 \mathrm{nM}$ ) (Burdette et al. 2001). However, Zinpyr-1 does not only detected "free" but also weakly protein bound $\mathrm{Zn}$ and the pool of $\mathrm{Zn}$ detectable by Zinpyr-1 is measured. Further, the content of $\mathrm{Zn}$ in $\mathrm{ZnAA}$ preparations was determined by AAS (Fig. S1c). As ZnAA solutions were prepared according to the MW of ZnAAs from powder that may contain traces of moisture and bisulfate acting as $\mathrm{Zn}$ donor in the production process, final concentrations measured for ZnAAs were slightly lower as calculated and the concentration of ZnAA used in the experiments adjusted to deliver an equivalent of $\mathrm{Zn}$ compared to $\mathrm{Zn}$-delivery by $\mathrm{ZnCl}_{2}$ solution $(50 \mu \mathrm{M})$.

As expected, treatment of cells with $\mathrm{ZnCl}_{2}$ solution led to a significant increase in $\mathrm{Zn}$ concentrations (ANOVA on ranks, $\mathrm{H}=94.125, p<0.001$, Dunn's multiple comparison test: Control vs. $\mathrm{ZnCl}_{2}$ $p<0.0001)$. Similarly, ZnGlu, ZnLys/Glu and ZnLys/Glu/Met significantly increased intracellular Zn (Fig. 1b) (Control vs. ZnGlu $p=0.0028$, Control vs. ZnLys $p=0.0741$; Control vs. ZnLys/Glu $p<$ 0.0001; Control vs. ZnLys/Glu/Met $p=0.0144$ ). $\mathrm{ZnCl}_{2}$ solution showed stronger effects compared to ZnMet and ZnLys $\left(\mathrm{ZnCl}_{2}\right.$ vs. ZnLys $p=0.0138$; $\mathrm{ZnCl}_{2}$ vs. ZnMet $\left.p=0.0004\right)$. 120 min after application, $\mathrm{ZnCl}_{2}$ solution and all $\mathrm{ZnAAs}$ increased intracellular $\mathrm{Zn}$ levels (one-way ANOVA, $\mathrm{F}_{6.69}=21.619$, $p<0.0001$, Bonferroni post hoc analysis: Control vs. $\mathrm{ZnCl}_{2}$, ZnGlu, ZnLys, ZnMet, ZnLys/Glu, ZnLys/ Glu/Met $p<0.0001$ ), although ZnMet increased intracellular $\mathrm{Zn}$ levels the least (Fig. 1c).

While application of Glu and Lys alone did not alter intracellular $\mathrm{Zn}$ levels compared to untreated controls, the application of Met alone, in turn, resulted in a significant increase in intracellular $\mathrm{Zn}$ (Fig. 1d), possibly due to secondary effects (one-way ANOVA, $\mathrm{F}=165.893, \quad p<0.001, \quad$ Bonferroni post hoc 
a

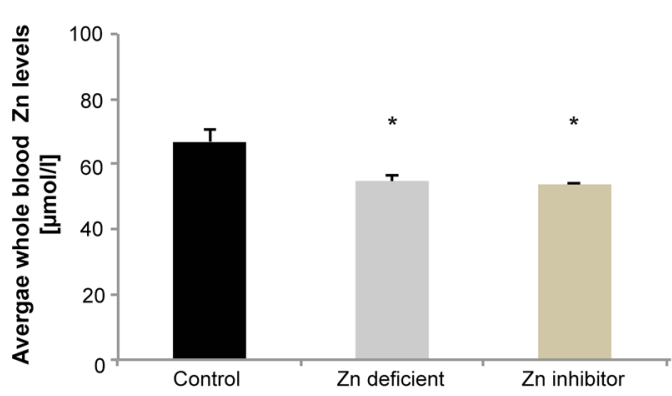

C
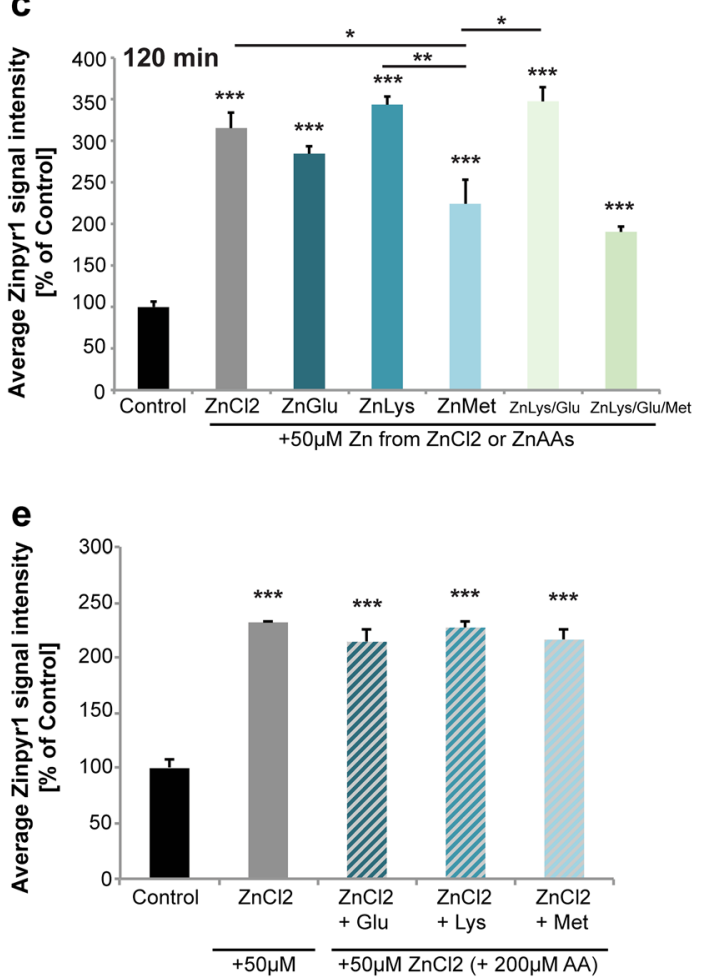

g

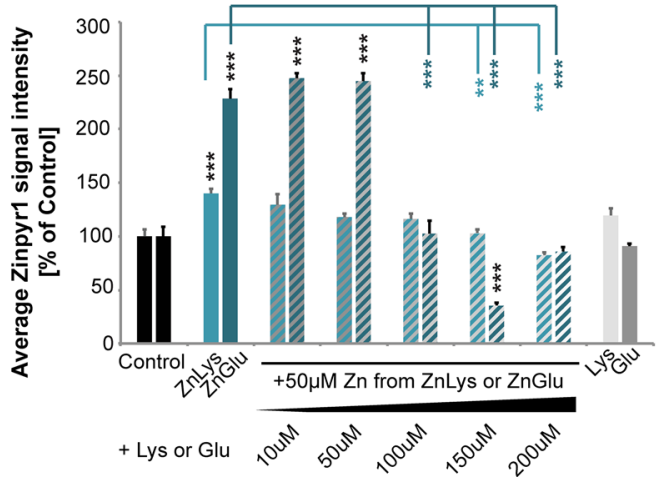

b

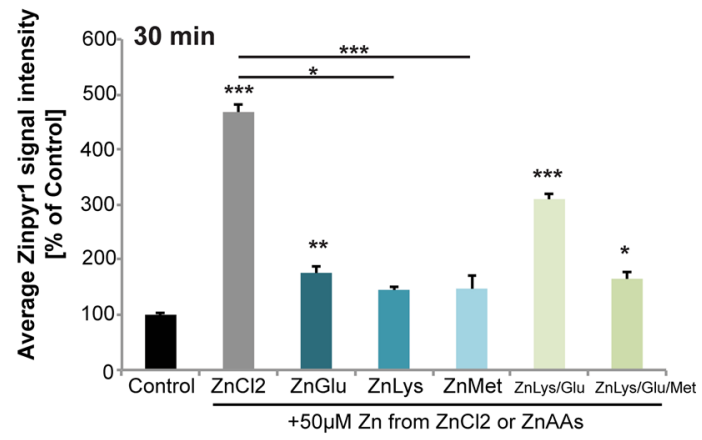

d

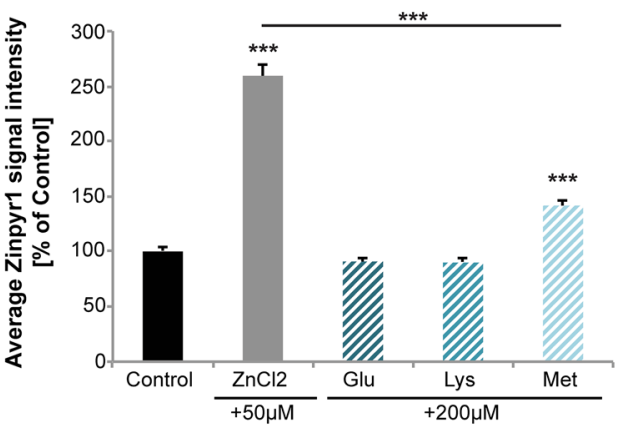

f

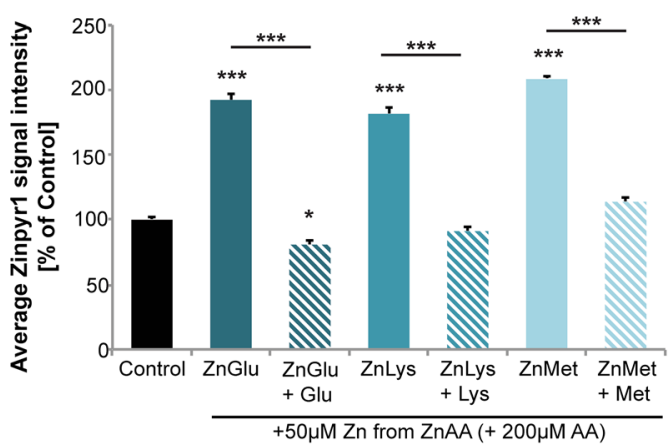

h

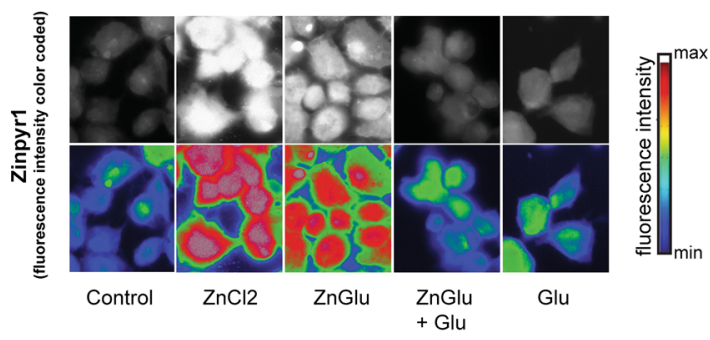


4Fig. 1 Uptake of $\mathrm{Zn}$ from ZnAAs in Caco-2 cells. a Blood levels of $\mathrm{Zn}$ from mice on different diets for 9 weeks. Wholeblood $\mathrm{Zn}$ levels were investigated by AAS in three animals per group. Animals on a $\mathrm{Zn}$ deficient diet (Diet 2) show significantly reduced $\mathrm{Zn}$ levels compared to mice on the control diet (Diet 1). Mice on the control diet with increased levels of $\mathrm{Zn}$ uptake antagonists (Diet 3) similarly show a significant reduction in blood-zinc levels. b-h Zinpyr-1 fluorescence intensity of Caco2 cells incubated for 30 min with $\mathrm{ZnCl}_{2}$ solution $(50 \mu \mathrm{M})$ or $\mathrm{ZnAAs}$ delivering an equivalent of $50 \mu \mathrm{M} \mathrm{Zn}{ }^{2+}$. b $\mathrm{ZnCl}_{2}$ solution, ZnGlu, and ZnLys/Glu and ZnLys/Glu/Met significantly increase intracellular $\mathrm{Zn}$. A trend for an increase was seen after application of $\mathrm{ZnLys}$ and $\mathrm{ZnMet}$. $\mathrm{ZnCl}_{2}$ solution increases intracellular $\mathrm{Zn}$ levels significantly more compared to $\mathrm{ZnLys}$ and $\mathrm{ZnMet}$ ( $n=10$ cells per group). c After $120 \mathrm{~min}, \mathrm{ZnCl}_{2}$ solution and all ZnAAs lead to a significant increase in intracellular $\mathrm{Zn}$ ( $n=10$ cells per group). d Application of Glu and Lys alone do not lead to differences in $\mathrm{Zn}$ compared to untreated controls. The application of Met alone results in a significant increase in intracellular $\mathrm{Zn}$ compared to controls, but significantly less than seen with $\mathrm{ZnCl}_{2}$ solution $(n=10)$. e The significant increase in intracellular $\mathrm{Zn}$ levels provided by $\mathrm{ZnCl}_{2}$ solution is not affected by the presence of a surplus of AAs in the medium. f A significant increase in intracellular $\mathrm{Zn}$ after application of ZnGlu, ZnLys, and ZnMet was not present when ZnGlu, ZnLys, and ZnMet were applied together with Glu, Lys and Met, respectively. $g$ The increase in intracellular $\mathrm{Zn}$ is reduced in a concentration dependent manner by co-application of $10,50,100,150$ and $200 \mu \mathrm{M}$ Lys or Glu, respectively $(n=10)$. h Exemplary images for Caco-2 cells stained with Zinpyr-1 are shown. The bottom row shows the Zinypr1 signal intensity color-coded

analysis: Control vs. $\mathrm{ZnCl}_{2}$, Met $p<0.0001 ; \mathrm{ZnCl}_{2}$ vs. Met $p<0.0001$ ). However, the uptake of free $\mathrm{Zn}$ provided via $\mathrm{ZnCl}_{2}$ solution was not affected by the presence of Glu, Lys or Met (Fig. 1e) (one-way ANOVA, $\mathrm{F}=53.22, p<0.0001$, Bonferroni post hoc analysis: Control vs. $\mathrm{ZnCl}_{2}, \mathrm{ZnCl}_{2}+$ Glu, $\mathrm{ZnCl}_{2}+$ Lys, $\mathrm{ZnCl}_{2}+$ Met, $p<0.0001$ ).

Next, we investigated whether the uptake of $\mathrm{Zn}$ provided by ZnAAs is inhibited by co-application of the corresponding AA. In contrast to the application of $\mathrm{ZnCl}_{2}$, a significant inhibitory effect on the increase in intracellular $\mathrm{Zn}$ levels after application of ZnGlu, ZnLys, and ZnMet was observed in presence of Glu, Lys and Met, respectively (Fig. 1f-h) (Fig. 1f: oneway ANOVA, $\mathrm{F}=157, p<0.0001$, Bonferroni post hoc analysis: Control vs. ZnGlu $p<0.0001$; Control vs. ZnGlu + Glu $p=0.027$; Control vs. ZnLys $p<$ 0.0001; Control vs. ZnMet $p<0.0001$; Fig. 1g Lys: one-way ANOVA, $\mathrm{F}=7.841, p<0.0001$, Bonferroni post hoc analysis: Control vs. ZnLys $p=0.007$, ZnLys vs. ZnLys + Lys (150) $p=0.003$, ZnLys vs. ZnLys + Lys (200) $p<0.0001$, ZnLys vs. ZnLys +
Lys (200) $p<0.0001 ;$ Fig. 1g Glu: one-way ANOVA, $\mathrm{F}=91.44, p<0.0001$, Bonferroni post hoc analysis: Control vs. ZnGlu $p<0.0001$, Control vs. ZnGlu + Glu (10) $p<0.0001$, Control vs. $\mathrm{ZnGlu}+$ Glu (50) $p<0.0001$, Control vs. ZnGlu + Glu (150) $p<0.0001$, ZnGlu vs. ZnGlu + Glu (100) $p<0.0001$, ZnGlu vs. ZnGlu + Glu (150) $p<$ 0.0001, ZnGlu vs. ZnGlu + Glu (200) $p<0.0001$ ). The inhibition of $\mathrm{Zn}$ uptake after application of ZnAAs via surplus of the corresponding AA follows a competitive manner as the increase in intracellular $\mathrm{Zn}$ is reduced in a concentration dependent manner by co-application of the AA (Fig. 1f). Thus, it is possible that $\mathrm{Zn}$ uptake, depending on the source $\left(\mathrm{ZnCl}_{2}\right.$ or ZnAAs) is mediated differently in Caco- 2 cells. Even $120 \mathrm{~min}$ after application of $\mathrm{ZnCl}_{2}$ solution and ZnAAs, similar mechanisms were detected (Fig. S2a, b) hinting towards stability of ZnAA complexes.

Uptake of Zn from ZnAAs is only partially affected by uptake antagonists

The presence of antagonists of $\mathrm{Zn}$ uptake such as increased amounts of $\mathrm{Ca}$ and $\mathrm{Cu}$ (Fig. 2a), phytic acid (PhytAc) (Fig. 2b), and folic acid (FolAc) (Fig. 2c) did not alter the significant increase in intracellular $\mathrm{Zn}$ levels $30 \mathrm{~min}$ after application of ZnAAs in most cases, but $\mathrm{Ca}$ and $\mathrm{Cu}$, as well as phytic acid and folic acid affected $\mathrm{Zn}$ uptake from $\mathrm{ZnCl}_{2}$. The presence of $50 \mu \mathrm{M} \mathrm{CuCl}_{2}$ and $50 \mu \mathrm{M} \mathrm{CaCl}_{2}$ significantly reduced $\mathrm{Zn}$ uptake from the $\mathrm{ZnCl}_{2}$ solution (Fig. 2a; ANOVA on ranks, $\mathrm{H}=142.288, p<0.0001$; Dunn's multiple comparisons test: $\mathrm{Ctrl}$ vs. $\mathrm{ZnCl}_{2}, p<0.0001 ; \mathrm{ZnCl}_{2}$ vs. $\mathrm{ZnCl}_{2}+\mathrm{Ca} / \mathrm{Cu}, p<0.0001$ ). The presence of $\mathrm{Ca}$ and $\mathrm{Cu}$ in contrast did not affect the uptake of $\mathrm{Zn}$ from ZnGlu, ZnLys, ZnMet, and ZnLys/Glu/Met (ZnGlu vs. ZnGlu $+\mathrm{Ca} / \mathrm{Cu}, p>0.999 ; \mathrm{ZnLys}$ vs. ZnLys + $\mathrm{Ca} / \mathrm{Cu}, p>0.9999$; ZnMet vs. ZnMet $+\mathrm{Ca} / \mathrm{Cu}, p>$ 0.999; ZnLys/Glu/Met vs. ZnLys/Glu/Met $+\mathrm{Ca} / \mathrm{Cu}$, $p>0.9999$ ). Although, as seen previously, $30 \mathrm{~min}$ after treatment with ZnLys and ZnMet, no significant increase in intracellular $\mathrm{Zn}$ levels was observed, the presence of $\mathrm{Ca}$ and $\mathrm{Cu}$ did not affect intracellular $\mathrm{Zn}$ concentrations.

The application of $2.5 \mathrm{mM}$ phytic acid similarly reduced the significant increase in intracellular $\mathrm{Zn}$ when $\mathrm{Zn}$ was added in the form of $\mathrm{ZnCl}_{2}$ (Fig. 2b; ANOVA on ranks, $\mathrm{H}=139.436, p<0.001$; Dunn's 
Fig. 2 Effect of antagonistic factors on uptake of $\mathrm{Zn}$ from $\mathrm{ZnAAs}$ in Caco- 2 cells. Zinpyr-1 fluorescence intensity of Caco-2 cells. a Application of $\mathrm{Zn}$ uptake antagonists calcium (provided as $\mathrm{CaCl}_{2}$ ) and copper (provided as $\mathrm{CuCl}_{2}$ ) together with $\mathrm{ZnCl}_{2}$ solution and ZnAAs. A significant inhibitory effect on $\mathrm{Zn}$ uptake from $\mathrm{ZnCl}_{2}$ solution is seen. No significant inhibition of the uptake of $\mathrm{Zn}$ delivered by ZnGlu, ZnLys, ZnMet, and ZnLys/Glu/Met was observed. The uptake of ZnLys/Glu was significantly inhibited. b Co-application of $\mathrm{Zn}$ uptake antagonist phytic acid (PhytAc). Coapplication of $\mathrm{ZnCl}_{2}$ and phytic acid leads to significantly less increase in intracellular $\mathrm{Zn}$ levels compared to cell treated only with $\mathrm{ZnCl}_{2}$ solution. No significant antagonistic effect was observed upon co-application of phytic acid and ZnGlu, ZnLys, ZnMet, ZnLys/Glu, and ZnLys/Glu/ Met. Uptake of ZnLys/Glu/ Met was higher in presence of phytic acid. Phytic acid was used in a molar ratio $\mathrm{Zn}:$ PhytAc $=1: 50$ $(n=10)$. c Co-application of Folic acid (FolAc). Significantly less $\mathrm{Zn}$ uptake via $\mathrm{ZnCl}_{2}$ solution (FolAc was used with $100 \mu \mathrm{M}$ concentration) is observed. A significant inhibitory effect on the uptake of ZnLys, ZnLys/Glu, and ZnLys/Glu/Met was observed. Only ZnGlu and ZnMet are unaffected, although ZnMet did not significantly increase intracellular $\mathrm{Zn}$ levels within 30 min (n.s. not significant)
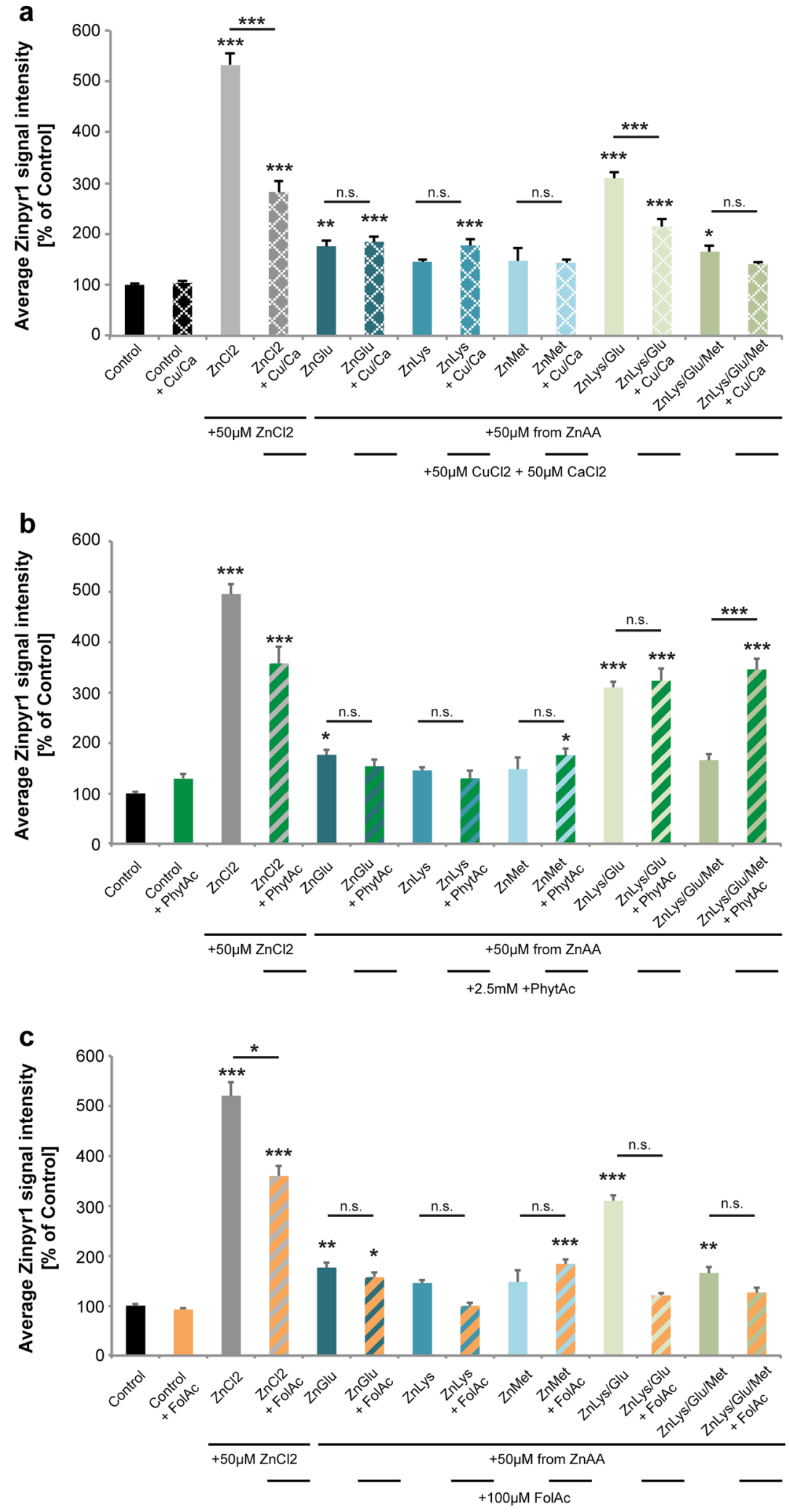
multiple comparisons test: $\mathrm{Ctrl}$ vs. $\mathrm{ZnCl}_{2}, p<0.0001$ ). In contrast, phytic acid did not significantly impair the increase caused by ZnGlu and ZnLys/Glu, and uptake of ZnLys/Glu/Met (ZnGlu vs. ZnGlu + PhytAc, $p>0.9999 ;$ ZnLys/Glu vs. ZnLys/Glu + PhytAc, $p>0.9999 ;$ ZnLys/Glu/Met vs. ZnLys/Glu/Met + PhytAc, $p>0.9999$ ). Again, ZnLys and ZnMet did not increase intracellular $\mathrm{Zn}$ levels significantly within 30 min of application, but phytic acid also did not affect $\mathrm{Zn}$ levels in these conditions (ZnLys vs. ZnLys + PhytAc, $p>0.9999$; ZnMet vs. ZnMet + PhytAc, $p>0.9999$ ).

The presence of folic acid (Fig. 2c) also affected the significant increase in intracellular $\mathrm{Zn}$ delivered by $\mathrm{ZnCl}_{2}$ solution (Fig. 2c; ANOVA on ranks, $\mathrm{H}=$ 134.578, $p<0.0001$; Dunn's multiple comparisons test: Ctrl vs. $\mathrm{ZnCl}_{2}, p<0.0001 ; \mathrm{ZnCl}_{2}$ vs. $\mathrm{ZnCl}_{2}+$ FolAc, $p=0.0482$ ). Again, no significant effect of FolAc on the increase in intracellular $\mathrm{Zn}$ levels caused by application of ZnGlu was seen (ZnGlu vs. $\mathrm{ZnGlu}+$ FolAc, $p=0.0537)$. Folic acid had no inhibitory effect on $\mathrm{Zn}$ in the form of ZnLys, ZnLys/ Glu, and ZnLys/Glu/Met (ZnLys vs. ZnLys + FolAc, $p>0.9999 ;$ ZnLys/Glu vs. ZnLys/Glu + FolAc, $p=0.0541 ; \mathrm{ZnLys} / \mathrm{Glu} / \mathrm{Met}$ vs. ZnLys/Glu/Met + FolAc, $p>0.9999$ ). ZnLys and ZnMet did not increase intracellular Zn levels significantly within 30 min of application, but folic acid also did not affect $\mathrm{Zn}$ levels significantly after application of ZnMet and even lead to a slight increase.

Thus, the significant intracellular increase in $\mathrm{Zn}$ levels after application of $\mathrm{ZnCl}_{2}$ solution was impaired by co-application of all antagonists tested. In contrast, the significant increase after application of ZnGlu was unaffected by any of the antagonists. All ZnAAs seem to be protected from inhibitory effects caused by phytic acid and folic acid.

$\mathrm{Zn}$ from $\mathrm{ZnAAs}$ is taken up by AA transporters in human enterocytes

To further investigate whether ZnAAs are taken up by AA transporters before dissociation of $\mathrm{Zn}$ from the AA, we performed uptake experiments using enterocytes differentiated from human induced pluripotent stem cells (hiPSC) from a healthy control and a patient with $A E$ (Fig. 3a-d). The underlying cause of $A E$ in this patient was identified by genome sequencing and the results revealed compound heterozygous mutations $192+19 \mathrm{G}>\mathrm{A}$ and $599 \mathrm{C}>\mathrm{T}$ (AA sequence Pro200Leu) in the hZIP4 gene. Thus, in this case, $\mathrm{Zn}$ uptake is inhibited by a genetic mutation in the major $\mathrm{Zn}$ importer. Differentiated cells from control and patient were identified as enterocytes by the expression of the marker proteins Sucrase-Isomaltase (SI) and Peptidase 1 (SLC15A1), and CDX2 and Villin (Fig. S3a, b). No difference in differentiation efficacy was found between control and patient.

After differentiating hiPSC to enterocytes (Fig. 3a), we again exposed the cells from a healthy control and $A E$ patient to $\mathrm{ZnCl}_{2}$ solution $(50 \mu \mathrm{M})$ or $\mathrm{ZnAAs}$ delivering an equivalent of $50 \mu \mathrm{M} \mathrm{Zn}$. Treatment with the $\mathrm{Zn}$ chelators TPEN confirmed the specificity of the Zinpyr-1 signal. 30 min after treatment, we measured the intracellular $\mathrm{Zn}$ levels by Zinpyr-1 staining (Fig. 3b-d). The results show that intracellular $\mathrm{Zn}$ levels in enterocytes of the healthy control are significantly increased after treatment with $\mathrm{ZnCl}_{2}$ solution as observed before in Caco-2 cells (Fig. 3b, ANOVA on ranks, $\mathrm{H}=52.424, p<0.0001$; Dunn's multiple comparisons test: Ctrl vs. $\mathrm{ZnCl}_{2}$, $p=0.0015)$. A significant increase in intracellular $\mathrm{Zn}$ was also observed upon treatment with $\mathrm{ZnGlu}$ (Ctrl vs. ZnGlu, $p<0.0001$ ), while ZnLys, ZnMet and ZnLys/Glu/Met did not significantly increase intracellular Zn within 30 min after application and the increase of ZnLys/Glu was statistically visible only as trend. All measured Zinpyr-1 fluorescence intensities were significantly different from the TPEN control.

In contrast, enterocytes differentiated from iPSCs from the $A E$ patient did not show a significant increase in intracellular $\mathrm{Zn}$ after treatment with $\mathrm{ZnCl}_{2}$ solution (Fig. 3c, d) (Fig. 3c: ANOVA on ranks, $\mathrm{H}=45.97$, $p<0.0001$; Dunn's multiple comparisons test: Ctrl vs. $\left.\mathrm{ZnCl}_{2}, p>0.9999\right)$. Compared to enterocytes differentiated from iPSCs from the Control, the uptake of $\mathrm{Zn}$ from $\mathrm{ZnCl}_{2}$ solution was significantly less (Fig. 3d: $\mathrm{ZnCl}_{2 \mathrm{Control}}$ vs. $\mathrm{ZnCl}_{2 \mathrm{AE}}, p<0.0001$ ). This is in line with the expectation that $\mathrm{Zn}$ delivered by $\mathrm{ZnCl}_{2}$ solution is mainly taken up by Zip4, which is severely functionally impaired in the $A E$ patient. In contrast, ZnAAs are taken up by enterocytes differentiated from the $A E$ patient and significantly increased intracellular $\mathrm{Zn}$ levels in case of $\mathrm{ZnLys} /$ Glu/Met (Fig. 3c: Ctrl vs. ZnLys/Glu/Met, $p=0.0071)$, and ZnGlu tended to increase intracellular Zn levels (Fig. 3c: Ctrl vs. ZnGlu, $p=0.0787$ ). All measured Zinpyr-1 fluorescence intensities were 
a

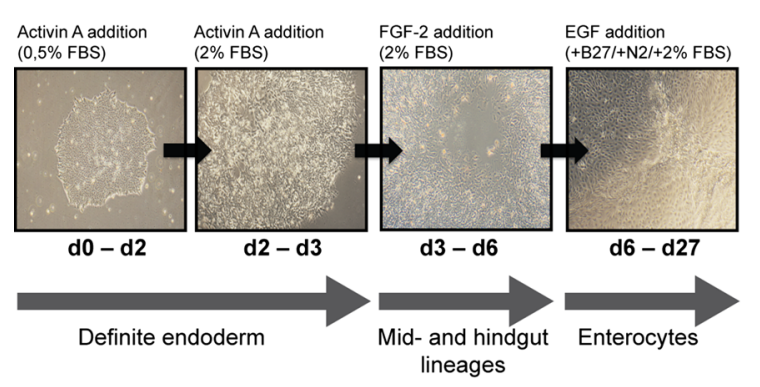

C

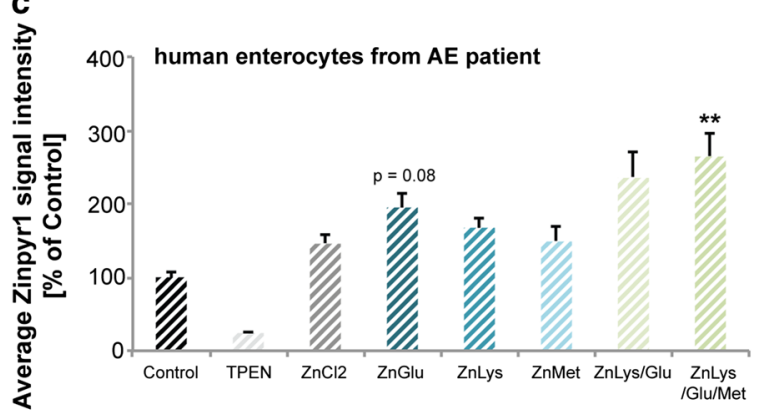

e

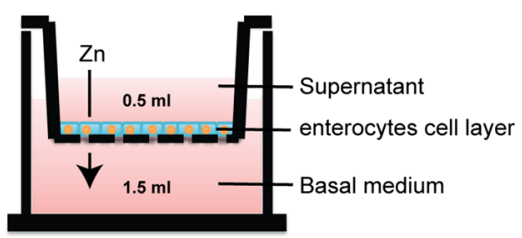

Transwell@ plate

g

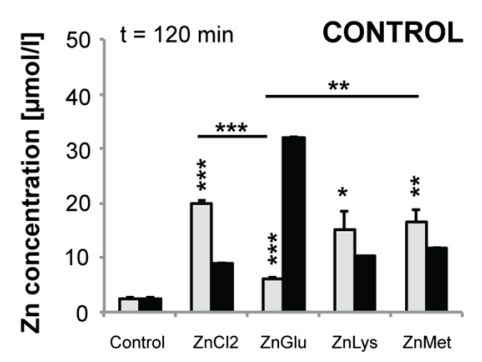

Supernatant

Basal medium

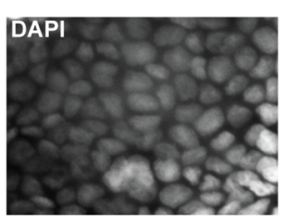

human enterocytes $100 \%$ confluent monolayer b

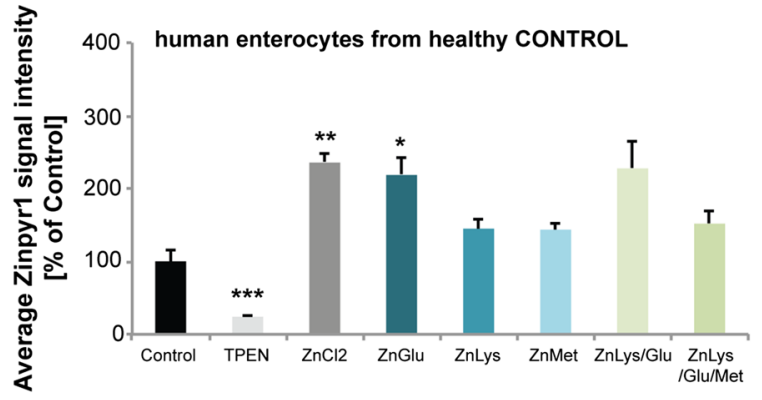

d

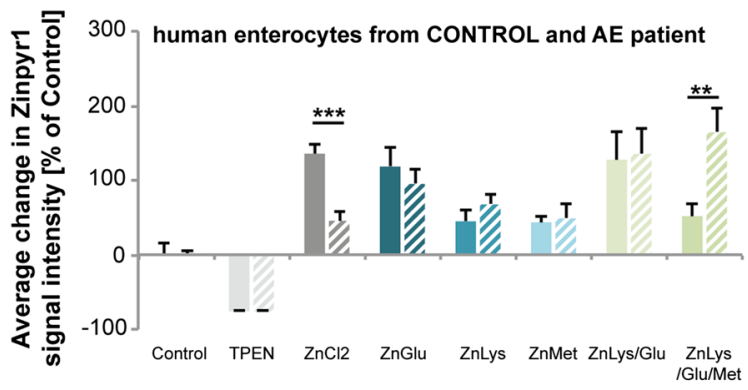

f

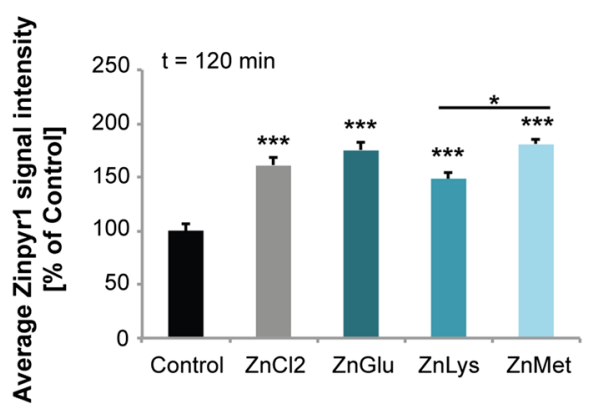

h

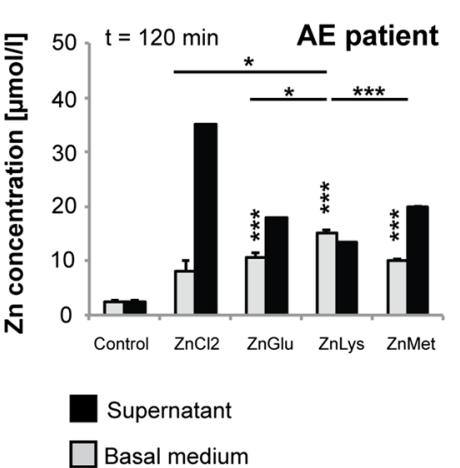

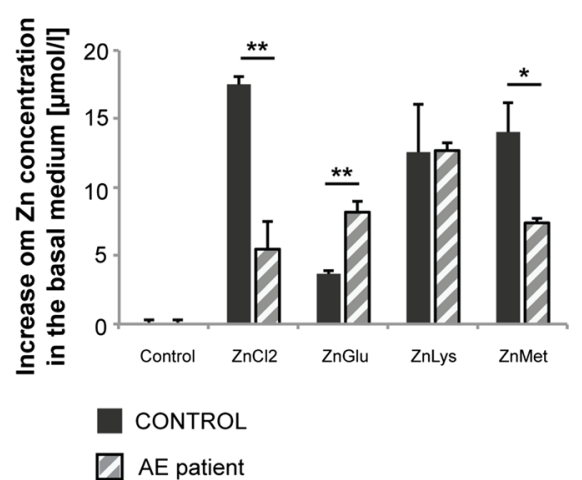

significantly different from the TPEN control. In contrast to uptake by $\mathrm{ZnCl}_{2}$ solution, uptake of $\mathrm{ZnAAs}$ is not significantly different between enterocytes from

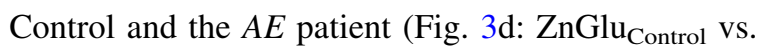
$\mathrm{ZnGlu}_{\mathrm{AE}}, p=0.4665$; $\mathrm{ZnLys}_{\mathrm{Control}}$ vs. ZnLys $\mathrm{ZE}_{\mathrm{AE}}$, $p=0.2688 ; Z_{\text {nMet }}$ Control vs. ZnMet ${ }_{\mathrm{AE}}, p=0.8083$; 
4Fig. $3 \mathrm{Zn}$ uptake in human enterocytes differentiated from healthy controls and patients with Acrodermatitis enteropathica. a Overview of the protocol for generation of enterocytes from hIPSC of a healthy control and AE patient. b, c Enterocytes were exposed to $\mathrm{ZnCl}_{2}$ solution $(50 \mu \mathrm{M})$ or $\mathrm{ZnAAs}$ delivering an equivalent of $50 \mu \mathrm{M} \mathrm{Zn}$ for $30 \mathrm{~min}$. Treatment with the $\mathrm{Zn}$ chelator TPEN confirmed the specificity of the Zinpyr-1 signal. b Intracellular $\mathrm{Zn}$ levels in enterocytes of the healthy control are significantly increased after treatment with $\mathrm{ZnCl}_{2}$ solution and ZnGlu. ZnLys, ZnMet, ZnLys/Glu and ZnLys/Glu/Met did not significantly increase intracellular $\mathrm{Zn}$ within $30 \mathrm{~min}$ after application. c Intracellular $\mathrm{Zn}$ levels in enterocytes of the $A E$ patient did not show a significant increase after treatment with $\mathrm{ZnCl}_{2}$. Application of $\mathrm{ZnLys} / \mathrm{Glu} / \mathrm{Met}$ (significant) and $\mathrm{ZnGlu}$ (as trend) leads to an increase in intracellular $\mathrm{Zn}$ levels. d A significant difference in uptake of $\mathrm{Zn}$ from $\mathrm{ZnCl}_{2}$ solution between enterocytes from Control and the $\mathrm{AE}$ patient was detected. Uptake of $\mathrm{ZnAAs}$ is not significantly lower in enterocytes from the $A E$ patient compared to the Control. Uptake from ZnLys/Glu/Met was significantly higher in cells from the AE patient. e Enterocytes differentiated from hIPSC were plated on the filter of a transwell ${ }^{\circledR}$ system. $\mathrm{ZnCl}_{2}$ solution or ZnAAs were applied to the supernatant. After $120 \mathrm{~min}$, the supernatant and the basal medium were removed. Cells on the filter were grown until they were $100 \%$ confluent and are visualized by DAPI staining of cell nuclei. f After incubation with $\mathrm{ZnCl}_{2}$ or $\mathrm{ZnAAs}$, a significant increase in Zinpyr-1 staining in cells $(n=10)$ was detected. $g$ Left: Using cells from the Control, all treatments resulted in a significant increase of $\mathrm{Zn}$ concentration in the basal medium (measured by AAS). The absorption of $\mathrm{ZnGlu}$ was significantly less compared to $\mathrm{ZnCl}_{2}$ solution and ZnMet. Right: Using cells from the $A E$ patient, incubation with $\mathrm{ZnCl}_{2}$ solution did not result in a significant increase of $\mathrm{Zn}$ concentration in the basal medium compared to untreated control cells, while application of all ZnAAs significantly increase the $\mathrm{Zn}$ concentration in the basal medium. The absorption of ZnLys was significantly higher compared to $\mathrm{ZnCl}_{2}$ solution, $\mathrm{ZnGlu}$ and $\mathrm{ZnMet}$. $\mathbf{h}$ Comparing the healthy control and the $\mathrm{AE}$ patent, significant differences were detected in the absorption of $\mathrm{Zn}$ from $\mathrm{ZnCl}_{2}$ solution and after application of $\mathrm{ZnGlu}$ and $\mathrm{ZnMet}$

ZnLys/Glu Control $_{\text {vs. ZnLys/Glu }}$ AE, $p=0.8772$ ) with exception of ZnLys/Glu/Met which significantly increased intracellular $\mathrm{Zn}$ level in cells from the $\mathrm{AE}$ patient $30 \mathrm{~min}$ after application (Fig. 3d: ZnLys/Glu/ Met $_{\text {Control vs. ZnLys/Glu/Met }}$ AE, $\left.p=0.0055\right)$.

Enterocytes differentiated from control iPSC also display similar uptake of compounds and $\mathrm{ZnCl}_{2}$ solution compared to Caco-2 cells in presence of uptake antagonists (Fig. S3c). 30 min after treatment with $\mathrm{ZnCl}_{2}$ solution or $\mathrm{ZnGlu}$, a significant increase in intracellular Zinpyr-1 fluorescence was detected (ANOVA on ranks, $\mathrm{H}=36.342, p<0.0001$; Dunn's multiple comparisons test: $\mathrm{Ctrl}$ vs. $\mathrm{ZnCl}_{2}, p<0.0001$; Ctrl vs. ZnGlu, $p=0.0103$ ). While uptake of $\mathrm{Zn}$ from $\mathrm{ZnCl}_{2}$ solution was significantly impaired by $\mathrm{Ca}, \mathrm{Cu}$, and phytic acid and tended to be impaired by folic acid (ANOVA on ranks, $\mathrm{H}=36.8, p<0.0001$; Dunn's multiple comparisons test: $\mathrm{ZnCl}_{2}$ vs. $\mathrm{ZnCl}_{2}+\mathrm{Ca} / \mathrm{Cu}$, $p<0.0001 ; \mathrm{ZnCl}_{2}$ vs. $\mathrm{ZnCl}_{2}+$ PhytAc, $p<0.0001$; $\mathrm{ZnCl}_{2}$ vs. $\mathrm{ZnCl}_{2}+$ FolAc, $p=0.0804$ ), uptake of ZnGlu was not significantly affected by presence of antagonists (ANOVA on ranks, $\mathrm{H}=1.515$, $p=0.6787$ ). Although application of ZnLys and ZnMet did not result in significant increases in intracellular Zinpyr-1 fluorescence within $30 \mathrm{~min}$, a significant alteration of $\mathrm{Zn}$ levels was only observed for ZnLys in presence of FolAc (ANOVA on ranks, $\mathrm{H}=28.51, p<0.0001$; Dunn's multiple comparisons test: ZnLys vs. ZnLys + FolAc, $p=0.0003$ ) and for ZnMet in presence of $\mathrm{Ca} / \mathrm{Cu}$ (ANOVA on ranks, $\mathrm{H}=14.68, p<0.0001$; Dunn's multiple comparisons test: ZnLys vs. ZnLys + FolAc, $p<0.0001)$.

$\mathrm{Zn}$ from $\mathrm{ZnAA}$ is absorbed in similar quantity compared to free $\mathrm{Zn}$

Therefore, next, to study not only uptake but actual absorption, we used a transwell ${ }^{\circledR}$ system (Fig. 3e). Enterocytes differentiated from human iPS cells were plated on the filter of a transwell insert and grown until they were $100 \%$ confluent (Fig. 3e). To control for gaps, FITC Dextran was applied to some wells and the increase in fluorescence in the basal medium controlled (Fig. S4). $\mathrm{ZnCl}_{2}$ solution or $\mathrm{ZnAAs}$ were applied to the supernatant. After $120 \mathrm{~min}$, the supernatant and the basal medium (Fig. 3e) were removed and the transport of $\mathrm{Zn}$ through the layer of cells was determined by measuring the $\mathrm{Zn}$ concentration of supernatant and basal medium (Fig. 3g, h). The results show that 120 min after treatment, the intracellular $\mathrm{Zn}$ concentration was significantly elevated after incubation with $\mathrm{ZnCl}_{2}$ solution or $\mathrm{ZnAAs}$ (Fig. 3f) (one-way ANOVA, $F_{4.49}=19.316, p<0.0001$, Bonferroni post hoc analysis: Control vs. $\mathrm{ZnCl}_{2}$, ZnGlu, ZnLys, ZnMet $p<0.0001)$. In enterocytes differentiated from iPSC from the Control, incubation with $\mathrm{ZnCl}_{2}$ solution $(50 \mu \mathrm{M} \mathrm{Zn})$ or $\mathrm{ZnAAs}(50 \mu \mathrm{M} \mathrm{Zn})$ resulted in a significant increase of $\mathrm{Zn}$ concentration in the basal medium compared to untreated control cells (one-way ANOVA, $\mathrm{F}=53.716, p<0.0001$, Bonferroni post hoc analysis: Control vs. $\mathrm{ZnCl}_{2}, p<0.0001$, Control vs. ZnGlu, $p=0.0006$; Control vs. ZnLys, $p=$ 0.0238; Control vs. ZnMet $p=0.0029)$. However, the absorption of ZnGlu was significantly less 
compared to $\mathrm{ZnCl}_{2}$ solution and $\mathrm{ZnMet}\left(\mathrm{ZnCl}_{2}\right.$ vs. ZnGlu, $p<0.0001$; ZnGlu vs. ZnMet $p=0.0085$ ). In enterocytes differentiated from iPSC from the $A E$ patient, incubation with $\mathrm{ZnCl}_{2}$ solution $(50 \mu \mathrm{M} \mathrm{Zn})$ did not result in a significant increase of $\mathrm{Zn}$ concentration in the basal medium compared to untreated control cells (one-way ANOVA, $\mathrm{F}=30.691, p<0.0001$, Bonferroni post hoc analysis: Control vs. $\mathrm{ZnCl}_{2}$, $p=0.0544)$. In contrast, application of ZnAAs (50 $\mu \mathrm{M} \mathrm{Zn)} \mathrm{resulted} \mathrm{in} \mathrm{a} \mathrm{significant} \mathrm{increase} \mathrm{of} \mathrm{Zn}$ concentration in the basal medium (Control vs. ZnGlu, $p=0.0008$; Control vs. ZnLys, $p<0.0001$; Control vs. ZnMet $p<0.0001)$. The absorption of ZnLys was significantly higher compared to $\mathrm{ZnCl}_{2}$ solution, ZnGlu and ZnMet $\left(\mathrm{ZnCl}_{2}\right.$ vs. ZnLys, $p=0.0259$; ZnGlu vs. ZnLys $p=0.0103$; ZnMet vs. ZnLys $p=0.0008$ ) (Fig. 3g).

Thus, while uptake of $\mathrm{Zn}$ into cells is faster by $\mathrm{ZnCl}_{2}$ compared to most ZnAAs after $30 \mathrm{~min}$, uptake is similar after $120 \mathrm{~min}$, which is reflected in similar levels of absorption after 120 min with slight advantage for ZnLys. Comparing enterocytes from the healthy control and the AE patent (Fig. 3h), significant differences can be detected (one-way ANOVA, $\mathrm{F}=42.013, p<0.0001$ ). Post hoc analyses reveal a difference in absorption of $\mathrm{Zn}$ from $\mathrm{ZnCl}_{2}$ solution $\left(\mathrm{ZnCl}_{2}\right.$ Control vs. $\left.\mathrm{ZnCl}_{2} \mathrm{AE}, p=0.0047\right)$ that was significantly less in cells from the AE patient. Further differences were detected after application of ZnGlu, which was significantly better absorbed in cell from the AE patient $\left(\mathrm{ZnGlu}_{\mathrm{Control}}\right.$ vs. $\left.\mathrm{ZnGlu}_{\mathrm{AE}}, p=0.0073\right)$, and ZnMet $\left(\right.$ ZnMet $_{\text {Control }}$ vs. ZnMet AE $_{\text {, }} p=0.0373$ ) that showed less absorption in cell from the AE patient compared to cells from the healthy control.

\section{Uptake of $\mathrm{Zn}$ by $\mathrm{ZnAAs}$ does not affect $\mathrm{Zn}$ and AA importer expression or localization}

Homeostasis of intracellular $\mathrm{Zn}$ concentrations, under physiological conditions, is maintained in cells by specific regulatory pathways. An increase in intracellular $\mathrm{Zn}$, for example, leads to $\mathrm{Zn}$ binding to the metal transcription factor-1 (MTF1) that translocates into the nucleus in a Zn-bound state. There, MTF-1 binds to specific sequences, so called metal response elements (MREs) in the promoter region of target genes, among them ZnT1. This increases the mRNA expression levels of $\mathrm{ZnT} 1$ and subsequently protein numbers. Given that $\mathrm{ZnT1}$ is a Zn exporter, this increase leads to a reduction
Fig. 4 Physiological responses to $\mathrm{Zn}$ uptake in Caco-2 cells. a Quantification of gene expression levels using qRT-PCR. The average mRNA expression ( $\Delta$ ct value) normalized to HMBS is shown compared to untreated (control) cells. Cells were treated with $\mathrm{ZnCl}_{2}(50 \mu \mathrm{M}), \mathrm{ZnGlu}$ (delivering an equivalent of $50 \mu \mathrm{M}$ ), ZnGlu and Glu $(200 \mu \mathrm{M})$, or Glu $(200 \mu \mathrm{M})$ alone. No significant changes were detected for the Zn transporters ZIP2 and ZnT1. Expression of ZnT1 shows high dynamics and a clear trend towards an up-regulation. ZIP4 levels are significantly different between cells treated with Glu compared to $\mathrm{ZnCl}_{2}$ and $\mathrm{ZnGlu}$ treatment. Amino acid transporters (SLC1A1, SLC7A6, SLC7A8 and SLC6A14) are unaffected by the treatments. SLC36A1 is significantly up-regulated after treatment with ZnGlu + Glu and shows significantly different expression in response to ZnGlu vs. Glu alone. SLC36A2 shows significantly increased expression after treatment with $\mathrm{ZnCl}_{2}$ and $\mathrm{ZnGlu}$ (as a trend) ( $n=3$ per condition). b-d Expression of Zip2, Zip4 and ZnT1 on protein level using Western Blot. The integrated density of 3 immunoreactive bands per condition was measured. b $30 \mathrm{~min}$ after application of $\mathrm{ZnCl}_{2}$ and $\mathrm{ZnGlu,} \mathrm{no} \mathrm{significant} \mathrm{regulation} \mathrm{can} \mathrm{be}$ detected on protein level. c After $120 \mathrm{~min}$, no alterations are detected regarding total Zip2 and Zip4 levels. A significant decrease in total cell $\mathrm{ZnT} 1$ concentration is observed after treatment with $\mathrm{ZnCl}_{2}$ or $\mathrm{ZnGlu}$. d Exemplary western blot bands for the evaluation of Zip2, Zip4, ZnT1 and SLC36A1, SLC36A2, and SLC6A14 protein levels after $120 \mathrm{~min}$. e The AA transporter SLC6A14 shows an up-regulation on total protein level after $120 \mathrm{~min}$ only after treatment with ZnGlu. No significant difference is detected for SLC36A1 and SLC36A2. f Immunocytochemistry was performed on Caco- 2 cells $(n=10$ per condition) and the fluorescence intensity of SLC6A14, Zip2, Zip4 and ZnT1 signals measured 120 min after treatment. A significant decrease of cell surface SLC6A14 signals after treatment with $\mathrm{ZnLys}$ but not the other $\mathrm{ZnAAs}$ is detected. Application of Lys alone does not elicit these alterations. Glu treatment slightly enhances SLC6A14 surface localization. For Zip2, no significant differences are detected in cell surface location, although a trend towards a reduction after $\mathrm{ZnCl}_{2}$ treatment and treatment with ZnAAs is seen (significant for $\mathrm{ZnCl}_{2}$ vs. Glu). No significant differences are detected in cell surface location of Zip4. The levels of ZnT1 at the cell surface were significantly increased after treatment with both $\mathrm{ZnCl}_{2}$ solution and ZnAAs, despite the decrease in total protein levels (c)

of intracellular $\mathrm{Zn}$ levels maintaining initial $\mathrm{Zn}$ homeostasis. We therefore quantified the expression levels and subcellular localization of selected candidate genes such as ZIP2, ZIP4 and ZnT1 on mRNA and protein level. Both, ZIP2 and ZIP4 have been shown to regulate $\mathrm{Zn}$ uptake into enterocytes. The level of mRNA abundance and subcellular localization of ZIP4 were reported to change in response to $\mathrm{Zn}$ levels (DufnerBeattie et al. 2003).

Alternatively, $\mathrm{Zn}$ complexes with AAs might bypass this system and might be taken up as well as exported, in part, via AA transporters. Thus, we additionally analyzed selected candidate genes such as 
a

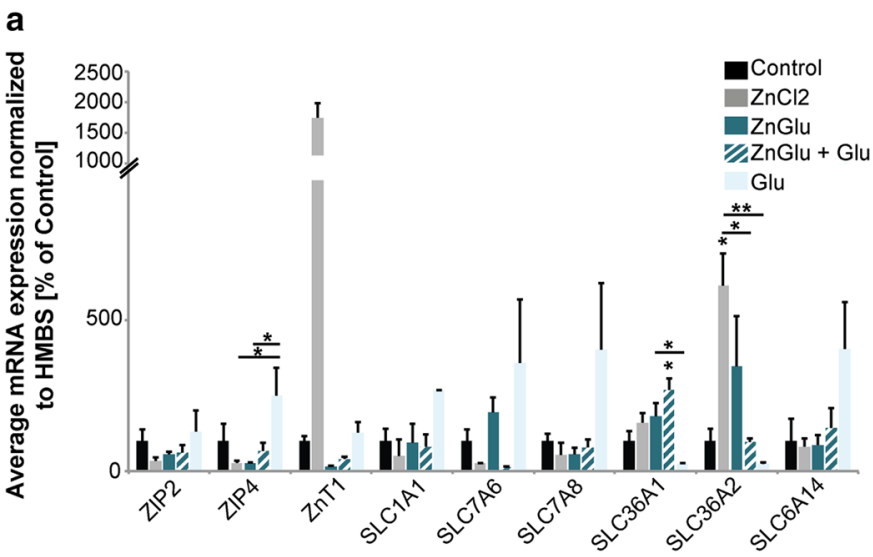

b
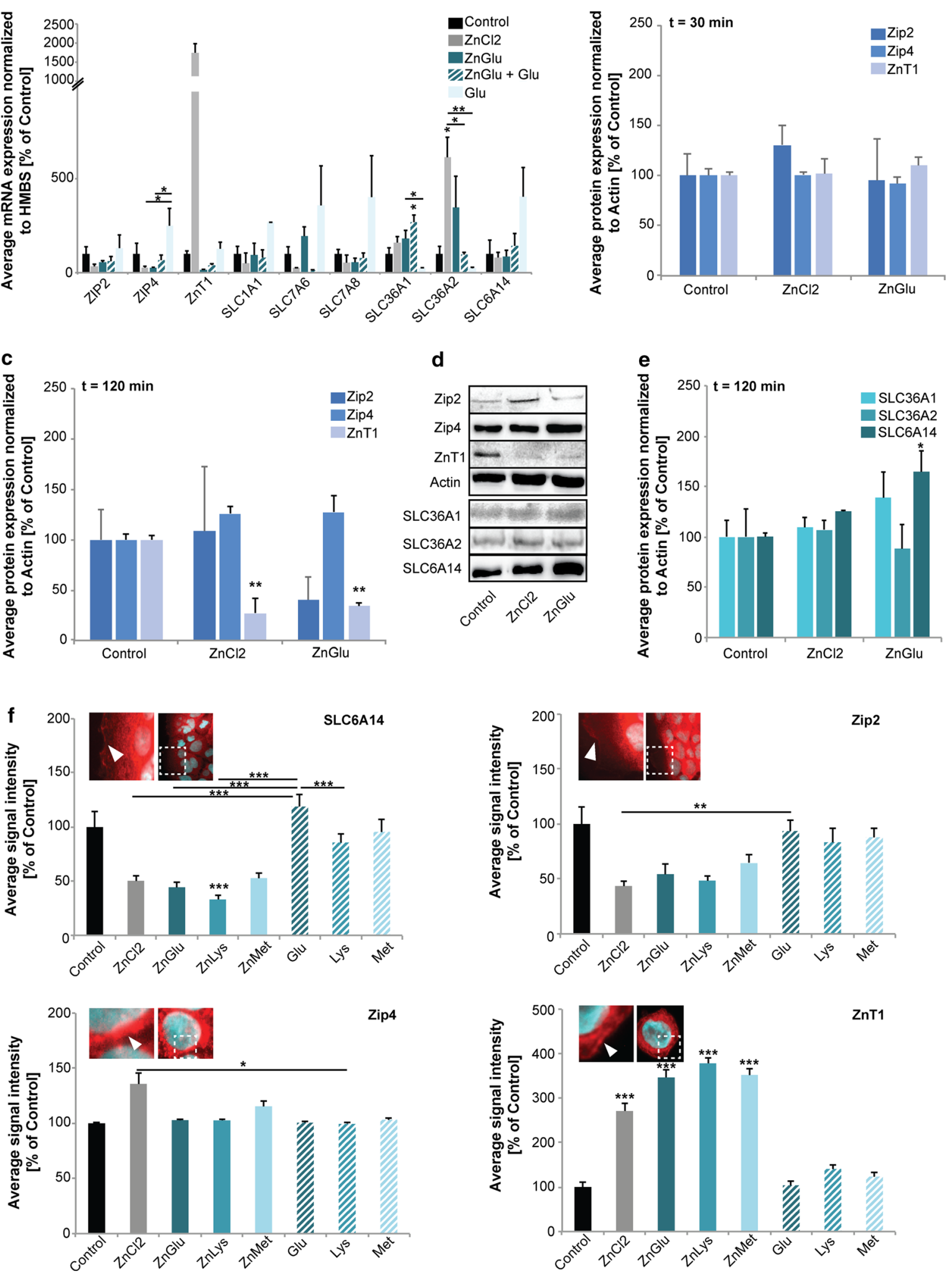
AA transporters SLC1A1, SLC7A6, SLC7A8, SLC6A14, SLC36A1 and SLC36A2 on mRNA and protein level (Fig. 4). SLC7A6, SLC7A8, SLC36A1 and SLC3A2 are sodium-independent AA transporters expressed in enterocytes and Caco- 2 cells, mediating the uptake of a wide range of AAs including Met, Lys and Glu. SLC1A1 and SLC6A14 are sodium-dependent AA transporters.

Our results reveal no significant changes of $\mathrm{Zn}$ transporters compared to controls in response to $\mathrm{ZnCl}_{2}$ solution or ZnAAs, although expression levels of $\mathrm{ZnT} 1$ are highly increased after administration of $\mathrm{ZnCl}_{2}$ (Fig. 4a). The AA transporters (SLC1A1, SLC7A6, SLC7A8 and SLC6A14) are unaffected by any of the treatments (Fig. 4a: one-way ANOVA, $p>0.05$ ). However, SLC36A2 is significantly up-regulated on mRNA level after treatment with $\mathrm{ZnCl}_{2}$ solution (oneway ANOVA, $\mathrm{F}_{4.14}=7.608, p=0.004$, Bonferroni post hoc analysis: Control vs. $\mathrm{ZnCl}_{2} p=0.021$ ).

To test whether differences might occur on protein level rather than in gene expression, we quantified the expression of Zip2, Zip4 and ZnT1 using Western Blot analysis (Fig. 4b-d). 30 min after application of $\mathrm{ZnCl}_{2}$ and $\mathrm{ZnGlu}$, no significant regulation can be detected on protein level (Fig. 4b, one-way ANOVA, ZIP2: $\mathrm{F}_{2.8}=0.2954 \quad p=0.7545 ; \quad$ ZIP4: $\quad \mathrm{F}_{2.8}=0.4382$ $\left.p=0.6643 ; \mathrm{ZnT} 1: \mathrm{F}_{2.8}=0.1858 p=0.8351\right)$. After $120 \mathrm{~min}$, no changes were detected in Zip2 (one-way ANOVA, $\left.\mathrm{F}_{2.8}=0.754 p=0.51\right)$ and Zip4 $\left(\mathrm{F}_{2.8}=\right.$ $2.201 p=0.192$ ), and a down-regulation of total cellular ZnT1 protein was found for both treatment groups (one-way ANOVA, $\mathrm{F}_{2.8}=19.088 p=0.003$; Bonferroni post hoc analysis: Control vs. $\mathrm{ZnCl}_{2}$ $p=0.004$; Control vs. ZnGlu $p=0.007$ ) (Fig. 4c, d). The AA transporter SLC6A14 showed a significant increase only in response to $\mathrm{ZnGlu}$ and not to $\mathrm{ZnCl}_{2}$ (Fig. 4d, e) (one-way ANOVA, $\mathrm{F}_{2.8}=7.102 p=$ 0.026; Bonferroni post hoc analysis: Control vs. $\mathrm{ZnCl}_{2}$ $p=0.584$; Control vs. ZnGlu $p=0.029$ ).

In addition to alterations in expression levels, the localization of transporters at the membrane might change. Thus, we additionally performed immunocytochemistry on treated Caco-2 cells and evaluated immuno-reactive signals at the cell surface of Zip2, Zip4, ZnT1 and SLC6A14 (Fig. 4f). The results show that a significant change occurs in SLC6A14 signals (one-way ANOVA, $\mathrm{F}_{7.79}=46.604 p<0.0001$ ). Bonferroni post hoc analysis reveals that the SLC6A14 fluorescence intensity at the membrane after treatment with ZnLys significantly decreases (Control vs. ZnLys $p<0.0001)$. Interestingly, treatment with Lys alone, but also treatment with $\mathrm{ZnCl}_{2}$ solution did not induce this change (Control vs. Glu $p=0.055$; Control vs. Lys $p=0$. 204; Control vs. $\mathrm{ZnCl}_{2} p=0$. 077). Zip2 membrane expression was not altered between the treatment groups and control, but a significant difference was found between treatment with $\mathrm{ZnCl}_{2}$ solution and Glu (one-way ANOVA, $\mathrm{F}_{7.79}=20.720 p=0.003$; Bonferroni post hoc analysis: $\mathrm{ZnCl}_{2}$ vs. Glu $p=0.002$ ). Membrane Zip4 levels were significantly altered (ANOVA on ranks, $\mathrm{H}=21.52 p=0.0031$; Dunn's post hoc test: $\mathrm{ZnCl}_{2}$ vs. Lys $\left.p=0.034\right)$. However, no significant alterations after application of $\mathrm{ZnCl}_{2}$ or ZnAAs compared to Control were observed. ZnT1 levels at the plasma membrane were significantly increased after both treatment with $\mathrm{ZnCl}_{2}$ solution and ZnGlu, ZnLys and ZnMet (one-way ANOVA, $\mathrm{F}_{7.79}=62.766 p<0.0001$; Bonferroni post hoc analysis: Control vs. $\mathrm{ZnCl}_{2} p<0.0001$; Control vs. ZnGlu, ZnMet and ZnLys $p<0.0001$ ).

Thus, taken together, application of ZnAAs does not elicit a homeostatic down-regulation of $\mathrm{Zn}$ importers on mRNA or protein level. However, treatment of Caco-2 cells with ZnAAs leads to an up-regulation of cell surface $\mathrm{ZnT} 1$ leading to $\mathrm{Zn}$ export. In the gastrointestinal tract, this export would be directed to the blood circulation. In addition, application of ZnAAs also does not lead to major compensatory regulations of AA transporters. Thus, $\mathrm{Zn}$ uptake from ZnAAs over time is not reduced, possibly bypassing homeostatic mechanisms that diminish Zn uptake upon chronic exposure to high $\mathrm{Zn}$ levels.

\section{Discussion}

$\mathrm{Zn}$ is absorbed from our dietary sources and/or supplements in the proximal small intestine, either the distal duodenum or proximal jejunum (Krebs et al. 1998; Lee et al. 1989) and released in the blood stream via transporters. However, various agents present in the diet can decrease $\mathrm{Zn}$ absorption (Cousins 2010). To prove this in an in vivo situation, we used mice and fed them a special diet containing either adequate $\mathrm{Zn}$ concentrations, inadequate $\mathrm{Zn}$ concentrations, or adequate $\mathrm{Zn}$ concentrations in presence of increased levels of $\mathrm{Zn}$ uptake antagonists such as phytic acid, $\mathrm{Ca} / \mathrm{Fe}$, and folic acid. Control animals displayed 
normal $\mathrm{Zn}$ levels in whole-blood in a magnitude as reported before (Grabrucker et al. 2016). As expected mice on a $\mathrm{Zn}$ deficient diet showed a significant reduction of $\mathrm{Zn}$ levels in the blood after 9 weeks. As whole-blood $\mathrm{Zn}$ was investigated, this reduction does not only reflect decreased $\mathrm{Zn}$ levels of a fast exchanging pool of plasma $\mathrm{Zn}$, but indicated a systemic $\mathrm{Zn}$ deficiency affecting intracellular $\mathrm{Zn}$ levels in several tissues. An important finding is that a similar $\mathrm{Zn}$ deficiency is produced in animals fed the control diet with adequate $\mathrm{Zn}$ supply but with increased levels of $\mathrm{Zn}$ uptake antagonists. In addition, genetic mutations in $\mathrm{Zn}$ transporters such as Zip4 in $A E$, may significantly lower $\mathrm{Zn}$ uptake.

Today, suboptimal $\mathrm{Zn}$ intake that might also lead to secondary nutritional problems is present not only in many developing countries but also in industrial nations (Lönnerdal 2000). Supplementation with Zn has, among others, effects on linear growth (Brown et al. 1998), the immune system (Shankar and Prasad 1998), and pregnancy outcome (Goldenberg et al. 1995). Intriguingly, among individuals with Autism Spectrum Disorders (ASD), the incidence rate of $\mathrm{Zn}$ deficiency has been reported to be significantly higher compared to age matched healthy control subjects (Pfaender and Grabrucker 2014). In the light of these findings, maintaining adequate $\mathrm{Zn}$ status during pregnancy and early development might be a promising approach to prevent cognitive and neurobehavioral deficits later in life. However, in most cases and especially in industrialized nations, the cause of suboptimal $\mathrm{Zn}$ absorption is not an inadequate dietary intake of $\mathrm{Zn}$, but the presence of antagonists in the diet. Therefore, it is necessary to investigate the efficacy of different $\mathrm{Zn}$ compounds in their ability to deliver $\mathrm{Zn}$ despite the presence of inhibitory factors or abnormalities in $\mathrm{Zn}$ transporters.

Here, we investigated the route of absorption of ZnAA compounds. Our results show that $\mathrm{Zn}$ delivered by $\mathrm{ZnAAs}$ is taken up into cells in a similar magnitude as $\mathrm{Zn}$ delivered as free $\mathrm{Zn}$ (by $\mathrm{Zn}$ salts) after two hours, although uptake is slower. Similar results were reported before using $\mathrm{CuAAs}$, where the uptake of $\mathrm{CuAAs}$ was lower compared to inorganic $\mathrm{Cu}$ solution, but the amino acid complex forms facilitated $\mathrm{Cu}$ absorption in Caco- 2 cells. The enhanced absorption of CuAA appeared to be mediated by amino acid transporters (Gao et al. 2014). Bath application of 50 $\mu \mathrm{M} \mathrm{Zn}$ led to an approx. 3 fold increase in intracellular
$\mathrm{Zn}$ levels after two hours. In this study, changes in $\mathrm{Zn}$ levels induced by $\mathrm{ZnCl}_{2}$ or $\mathrm{ZnAA}$ supplementation are shown relative to controls. Measuring absolute $\mathrm{Zn}$ concentrations using Zinpyr-1 fluorescence signal intensities is difficult to perform, as several components, such as buffering proteins in the medium of cells that contains fetal bovine serum (FBS), introduce variables that may lead to a non-linear realtionship of $\mathrm{Zn}$ and fluorescence intensity. Further, quantitative measurements of $\mathrm{Zn}$ concentrations using fluorophores such as Zinpyr-1 are difficult, as not only free but also protein bound $\mathrm{Zn}$ is detected to some extent, and comparisons of relative values between $\mathrm{ZnCl}_{2}$ and $\mathrm{ZnAAs}$ may be more meaningful.

It was shown that with increasing amounts of $\mathrm{Zn}$ in a diet, the amount of $\mathrm{Zn}$ absorbed decreases (Lönnerdal 2000; Sandström and Cederblad 1980). This reduction in fractional absorption of zinc at higher doses most likely is due to the saturation of $\mathrm{Zn}$ transporters. For example, in humans after intestinal perfusion with solutions with increasing concentration of $\mathrm{Zn}$, first a linear increase in $\mathrm{Zn}$ absorption was observed. However, at higher concentrations, the rates leveled out (Lee et al. 1989).

Intriguingly, in cells from an $A E$ patient, no impairment in the absorption of ZnAAs was seen in contrast to $\mathrm{ZnCl}_{2}$. We could show that, at least in part, $\mathrm{ZnAA}$ are taken up via AA transporters. Thus, uptake of $\mathrm{Zn}$ from $\mathrm{ZnAAs}$ is not impaired in cells from an $A E$ patient with mutated ZIP4 gene, but inhibited by increased levels of AA competing with ZnAAs for AA transporters. Although uptake may also be mediated by other transporters such as DMT-1, it is unlikely that DMT-1 transports ZnAAs and is inhibited by AAs. Further, the structure of the ZnAAs makes it unlikely that they function as ionophores. AAs generally show poor membrane permeability (Chakrabarti 1994) and ZnAAs are structurally not drastically different from the corresponding AAs.

While we could not detect major changes in mRNA and total protein levels of zinc importers Zip2 and Zip4 after treatment with ZnAAs, similar to exposure to $\mathrm{ZnCl}_{2}$ solution, levels of membrane bound $\mathrm{ZnT} 1$ exporters were significantly increased as homeostatic control mechanism of cells to reduce increased intracellular Zn levels (Cousins 2010). However, we could not detect a reduction of AA transporters in response to $\mathrm{ZnAA}$. Given that $\mathrm{Zn}$ importer and AA importer levels are unaffected by exposure to 
increased levels of ZnAA, it is likely that the uptake of $\mathrm{Zn}$ by $\mathrm{ZnAA}$ is a process that will not be compensated by homeostatic regulation of AA transports and given the abundance of AA transporters will not be easily saturated. It might even be possible to increase $\mathrm{Zn}$ levels beyond physiological concentrations using ZnAAs.

$\mathrm{Zn}$ is likely to predominantly be transported as "free" $\mathrm{Zn}$ via a saturable, specific transport mechanism such as $\mathrm{Zn}$ importers from the ZIP family (Sandström 1992). This, however, makes the "free" $\mathrm{Zn}$ susceptible for competition with other metals and dietary ligands that may considerably lower the concentration of "free" $\mathrm{Zn}$. Zn delivery by $\mathrm{ZnAA}$, in particular ZnGlu, which is among the most stable ZnAAs tested, is less affected by uptake inhibitors compared to $\mathrm{Zn}$ delivery by "free" $\mathrm{Zn}$ from $\mathrm{ZnCl}_{2}$ solution. Especially high levels of $\mathrm{Ca}$ and $\mathrm{Cu}$ were not able to inhibit uptake of $\mathrm{Zn}$ via $\mathrm{ZnGlu}$ and ZnLys/Glu/Met in vitro.

Although it is unlikely that the level of $\mathrm{Cu}$ in the diet or in a supplement would reach the levels used in this study in vivo, an interaction of $\mathrm{Ca}$ and $\mathrm{Cu}$ has been described in experimental animals, albeit at very high ratios. Most likely, $\mathrm{Cu}$ and $\mathrm{Zn}$ compete on cellular level for binding partners necessary for absorption such as metallothioneins or metal transporters. However, the $\mathrm{Cu} / \mathrm{Zn}$ interaction is at present poorly understood. The data obtained through our studies argues for a possible competition already at the level of cellular uptake as the increase of intracellular $\mathrm{Zn}$ by application of "free" $\mathrm{Zn}$ was significantly decreased in presence of high $\mathrm{Ca}$ and $\mathrm{Cu}$ concentrations, but uptake of ZnGlu and other ZnAAs seemed unaffected.

Delivery of Zn by ZnGlu, ZnLys/Glu and ZnLys/ Glu/Met was also not affected by the presence of high levels of phytic acid. Animal experiments have shown that the absorption of $\mathrm{Zn}$ is inversely correlated to the concentration of phytic acid in the diet (Lönnerdal et al. 1988). The phosphate groups in phytic acid form insoluble complexes with $\mathrm{Zn}$, and phytate-bound $\mathrm{Zn}$ will be excreted in the feces, thereby causing an inhibitory effect on Zn absorption (O'Dell 1969; Vohra and Kratzer 1964). Phytate is present in staple foods like cereals, corn and rice, and the removal or reduction of phytate by methods such as phytase treatment or fermentation markedly improves $\mathrm{Zn}$ absorption. In case of $\mathrm{ZnAA}$, it is possible that $\mathrm{Zn}$ will not be as accessible as "free" $\mathrm{Zn}$ and thus less complex formation with phytic acid will occur.

Folic acid has been reported to increase fecal $\mathrm{Zn}$ excretion, which might indicate an inhibitory effect on Zn absorption (Ghishan et al. 1986; Simmer et al. 1987; Krebs 2000). Intriguingly, pregnant women are encouraged to supplement folic acid in their diet, as a lack of folic acid has been associated with birth defects such as spina bifida. However, recent studies suggest that excessive amounts of folate might increase the risk for the occurrence of ASD (Raghavan et al. 2016). One might speculate that the underlying patho-mechanism could be a prenatal $\mathrm{Zn}$ deficiency that has been shown to induce autism-like behavior in mice (Grabrucker et al. 2014, 2016; Grabrucker 2014).

Uptake of most ZnAAs tested was affected by the presence of folic acid, which might argue for a possible indirect interaction of folic acid with processes such as $\mathrm{Zn}$ homeostasis. However, we observed no significant influence of increased levels of folic acid on Zn delivery by ZnGlu. ZnGlu therefore might be an interesting compound if $\mathrm{Zn}$ should be supplemented together with folic acid.

Our result supports the need for a careful assessment of bioavailability of $\mathrm{Zn}$ in the human diet, as dietary habits may change and required daily dosages might need to be adjusted to prevent $\mathrm{Zn}$ deficiencies. Especially during pregnancy, consumption of supplements containing high folic acid and $\mathrm{Ca}$ and $\mathrm{Fe}$ concentrations may create the need for higher $\mathrm{Zn}$ intake to ensure maintenance of physiological $\mathrm{Zn}$ levels and possibly reduce the risk for neurodevelopmental disorders in the offspring.

Taken together, we conclude that $\mathrm{Zn}$ can be enriched in cell systems and animals using ZnAAs. The uptake of ZnAAs might be slower, however, uptake and absorption reaches a similar quantity compared to "free" Zn over time. Most importantly, the advantage of ZnAAs lies in their ability to utilize less saturable pathways for uptake and in the feature that ZnAA compounds are protected from antagonistic factors in the diet to some extent. Therefore, they might be a superior supplement in cases of genetic defects in pathways responsible for uptake of "free" $\mathrm{Zn}$, such as mutations in $\mathrm{Zn}$ transporters as seen in $A E$, or in case of diets with high concentrations of uptake antagonists and in combination with other supplements delivering $\mathrm{Cu}$ or folic acid for example. 


\section{Materials and methods}

Materials, chemicals and reagents

Zinpyr-1 was purchased from Sigma Aldrich. Primary antibodies were purchased from Synaptic Systems (ZnT1), Abcam (Zip2 (1:1000), Zip4 (1:125), SLC6A14), Acris (Zip4 (1:200)), Thermo Fisher (SLC36A1 (1:500)), Invitrogen (SLC36A2 (1:500)), and Sigma Aldrich ( $\beta$-Actin, (1:1000)). Secondary HRP conjugated antibodies were purchased from Dako (anti-rabbit 1:1000) and Dianova (anti-mouse 1:10,000). DMEM, DMEM/F12 GlutaMAX, RPMI advanced, Non-essential amino acids (NEAA), B27, N2, FBS and Antibiotic-Antimycotic were acquired from Gibco. Unless otherwise indicated, all other chemicals were of analytical grade and obtained from Sigma-Aldrich.

ZnAAs-Zinc amino acid complexes (ZnAAs) (Fig. S1a) were obtained from Zinpro Corporation (Eden Prairie, MN USA). ZnGlu, ZnMet, ZnLys and, to utilize as many amino acid transporters as possible (cationic, anionic and hydrophobic transporters), combinations were used. We chose lysine since it has an active transporter. It also has a stability constant greater than that of methionine in metal complexes (Furia 1975). The complex with $\mathrm{Zn}$ is between the carboxyl group and the alpha nitrogen. The side group may increase the stability but is not needed for binding. ZnAA structures with the complex between the acid and amine groups forming a 5 membered ring. The complexes are known to survive the stomach acid and get absorbed in animals based on the results of several studies where animals were supplemented with $\mathrm{ZnAA}$ or $\mathrm{ZnAA}$ in addition to inorganic $\mathrm{Zn}$ and significant differences were detected compared to supplementation with $\mathrm{Zn}$ salt (Nayeri et al. 2014). However, the stability of of ZnAAs in low stomach $\mathrm{pH}$ has not yet been directly determined.

ZnAA compounds were obtained as powder and solutions were freshly prepared for each experiment. The calculated MW for a ZnAA was taken into account to prepare the solutions.

Caco-2 colorectal adenocarcinoma cell line

Caco-2 cells (American Type Culture Collection $\left(\mathrm{ATCC}^{\circledR}\right.$ HTB-37 $\left.{ }^{\mathrm{TM}}\right)$ ) were used between passage 20 and 43 . The cells were maintained in $175-\mathrm{cm}^{2}$ flasks in Dulbecco's minimal essential medium (DMEM) supplemented with $10 \%$ fetal bovine serum, $1 \%$ non-essential amino acids (NEAA), 1\% L-Glutamine, and 1\% Antibiotic-Antimycotic 100× (Invitrogen). Cells were grown to $100 \%$ confluence on a 24 well plate or $10 \mathrm{~cm}$ petri dish. Treatment was performed on DIV 10, as Caco-2 cells differentiate spontaneously in culture to mature intestinal enterocytes within 21d, and we detected expression of $\mathrm{Zn}$ and AA transporters and enterocyte like morphology after $10 \mathrm{~d}$ in culture with no change until DIV 21, except for a decrease of ZIP4 in Caco-2 cells older than 10 DIV (Fig. S5a-c).

Animals

Female C57BL/6JRj mice were purchased from Janvier labs. Mice ( 8 weeks of age) were habituated for two weeks (receiving the same diet). Subsequently, mice received a special laboratory diet (ssniff $\mathrm{GmbH}$, Germany; Supplementary data 1) with access to food and water ad libitum for 9 weeks. Animals on $\mathrm{Zn}$ deficient diet received distilled water; all other groups had access to tap water. Three animals per group were analyzed. All animal experiments were performed in compliance with the guidelines for the welfare of experimental animals issued by the Federal Government of Germany and by the local ethics committee (Ulm University) ID Number: 1257.

Generation of iPSC from a patient with Acrodermatitis enteropathica

After informed consent, keratinocytes were obtained from plucked human hair and plated on matrigel diluted 1:10 in EpiLife (Gibco). Plated hair was cultivated in MEF conditioned medium supplemented with 10 ng/ml FGF2 (Cell Guidance Systems), 20 ng/ $\mathrm{ml}$ Ascorbic Acid (Sigma-Aldrich) and $10 \mu \mathrm{M}$ Rhoassociated kinase (ROCK) inhibitor (Ascent Scientific) and medium changed to Epilife supplemented with $10 \mu \mathrm{M}$ ROCK inhibitor after keratinocyte outgrowth. IPSC lines were reprogrammed from human hair keratinocytes via lentiviral transduction as previously described with a multicistronic vector published by Warlich et al. (2011) (Linta et al. 2012). iPSC were cultured in mTeSR1 medium (Stemcell Technologies) on matrigel (BD Biosciences) coated 6-well plates at $37{ }^{\circ} \mathrm{C}, 5 \% \mathrm{CO}_{2}$ and $5 \% \mathrm{O}_{2}$. 
Stem cell-differentiation into enterocyte-like cells

The differentiation was performed using a protocol by Iwao et al. (2014). Human induced pluripotent stem cell lines between passages 15 and 20 were grown to $70 \%$ confluence in mTeSR 1 stem cell medium. Differentiation to definite endoderm was initiated by changing the medium to RPMI advanced supplemented with $2 \mathrm{mM}$ GlutaMAX, 0.5\% FBS, $100 \mathrm{ng} / \mathrm{ml}$ Activin A (Cell Guidance Systems) and 1\% Antibiotic-Antimycotic. After $48 \mathrm{~h}$, cells were grown in RPMI advanced supplemented with $2 \mathrm{mM}$ GlutaMAX, 2\% FBS, $100 \mathrm{ng} / \mathrm{ml}$ Activin A and 1\% Antibiotic-Antimycotic for $24 \mathrm{~h}$. The medium was changed to DMEM/F12 GlutaMAX containing 2\% FBS, $250 \mathrm{ng} / \mathrm{ml}$ FGF-2 (Cell Guidance Systems) and $1 \%$ Antibiotic-Antimycotic for $96 \mathrm{~h}$. Subsequently cells were treated with $10 \mu \mathrm{M}$ ROCK Inhibitor (Ascent Scientific) for $1 \mathrm{~h}$, detached with TrypLE and plated on Matrigel coated 12-well plates. The cells were cultured in DMEM/F12 + GlutaMAX, 2\% FBS, $1 \%$ NEAA, 2\% B27, 1\% N2, 20 ng/ml EGF (Invitrogen), and 1\% Antibiotic-Antimycotic. B27 and N2 were purchased from GIBCO. Medium was changed every 3 days. The cells were used after 3 weeks in culture (d21). Cells were grown to $100 \%$ confluence on a 24 well plate or a 12 well Corning ${ }^{\circledR} \operatorname{Costar}^{\circledR}$ Transwell $^{\circledR}$ plate with $3 \mu \mathrm{m}$ pore Polyester (PET) membrane insert and also used at $\mathrm{d} 21$. Confluency and leakage through gaps in the cell layer we controlled by microscopy and application of FITC Dextran, respectively. FITC Dextran fluorescence was determined using a fluorimeter (Jenway 62 series) and UV table.

Immunocytochemistry

After fixation in 4\% Paraformaldehyde/4\% Sucrose at room temperature for $15 \mathrm{~min}$, the cells were washed with PBS and permeabilized with $0.2 \%$ Triton X-100 in PBS for $5 \mathrm{~min}$ twice. Subsequently, blocking solution (BS; 10\% FBS in PBS) was applied at room temperature for $1 \mathrm{~h}$. Cells were incubated with the primary antibodies at $4{ }^{\circ} \mathrm{C}$ over night. After washing $3 \times$ with PBS, the cells were incubated with Alexa Fluor conjugated secondary antibody diluted 1:1000 in BS at room temperature for $1 \mathrm{~h}$. After washing $2 \times$ with PBS and $1 \times$ with sterile Millipore water, cells were mounted with ProLong ${ }^{\circledR}$ Gold antifade reagent with DAPI. Fluorescence images were obtained an upright Axioscope microscope equipped with a Zeiss CCD camera (16 bits; $1280 \times 1024$ ppi) using Axiovision software (Zeiss) and analyses of integrated densities was performed with ImageJ $1.50 \mathrm{~g}$.

Measurement of trace metal concentrations

For fluorescent Zn-staining of cultured cells, growth medium was discarded and the cells were washed with PBS. Coverslips were incubated with a solution of 50 $\mu \mathrm{M}$ Zinpyr-1 (Burdette et al. 2001) in PBS for $1 \mathrm{~h}$ at RT. The mean intracellular Zn concentration per cell was determined by Zinpyr-1 fluorescence intensity. Images were obtained using an Axioscope microscope and evaluated with Image J $1.50 \mathrm{~g}$. The $\mathrm{Zn}$-concentration of solutions and blood was measured by flame atomic absorption spectrometry (AAS) at the Department of Clinical Chemistry (ZE klinische Chemie) of the University Hospital Ulm using a PinAAcle 900T from Perkin Elmer and in the workgroup of Prof. Rink, Institute of Immunology, University Hospital Aachen using a Perkin Elmer AAnalyst 800 instrument. All reagents for atomic absorption were of appropriate quality for trace element analysis (TraceSelect, Fluka). Samples were diluted in ultrapure water containing $0.2 \%(\mathrm{v} / \mathrm{v}) \mathrm{HNO}_{3}$ and quantified with a standard curve between 0 and $1 \mathrm{mg} \mathrm{l}^{-1}$ zinc in $0.2 \%$ (v/v) $\mathrm{HNO}_{3}$, measuring the absorption at $213.9 \mathrm{~nm}$ (slit $0.7 \mathrm{~nm}$ ). A reference samples spiked with defined concentrations of $\mathrm{Zn}$ were routinely analyzed to ensure reliable quantification. Whole blood from mice was collected in Lithium-Heparin Microvettes (Sarstedt) and stored at $-20{ }^{\circ} \mathrm{C}$ until further analysis.

\section{Cell lysis and RNA preparation}

Cells were harvested and resuspended in $600 \mu 1$ RIPA buffer, and kept for $30 \mathrm{~min}$ on ice. Lysate was cleared from debris by centrifugation (14,000 rpm, $15 \mathrm{~min}$ ) and stored at $-80{ }^{\circ} \mathrm{C}$ with Protease Inhibitor. Total RNA was isolated from cell-pellets resuspended in RLT buffer with the RNeasy Mini Kit according to the manufacturer's protocol. All of the optional purification steps were performed and RNA eluted with sterile RNAse free water. 
qRT-PCR

First strand synthesis and quantitative real-time-PCR amplification were performed in a one-step, singletube format using the QuantiFast ${ }^{\mathrm{TM}}$ SYBR Green RTPCR kit from Qiagen according to the manufacturer's protocol in a total volume of $20 \mu \mathrm{l}$ and the Qiagen QuantiTect Primer Assays: Hs_CDX2_1_SG (QT000 37807), Hs_VIL1_1_SG(QT00095837), Hs_SLC39A 4_va.1_SG (QT01022637), Hs_HMBS_1_SG (QT00 014462), Hs_SLC39A2_1_SG(QT00213388), Hs_SL C30A1_1_SG (QT00096320), Hs_SLC1A1_1_SG (QT00065303), Hs_SLC7A6_1_SG (QT00052248), Hs_SLC7A8_1_SG (QT00006384), Hs_SLC36 A1_1_SG (QT00029281), Hs_SLC36A2_1_SG (QT0 0070875), Hs_SLC6A14_1_SG (QT00087542). The qRT-PCR was set up with the following program (Reverse Transcription, $50{ }^{\circ} \mathrm{C}, 10^{\prime}, 1$ cycle; Denaturation, $95^{\circ} \mathrm{C}, 5^{\prime}, 1$ cycle; [Denaturation, $95^{\circ} \mathrm{C}, 10^{\prime \prime}$, combined annealing/extension, $60^{\circ} \mathrm{C}, 30^{\prime \prime}$ ], 40 cycles; Melting curve analysis, 60-95 ${ }^{\circ} \mathrm{C}, 90^{\prime \prime}$ (first step, elevation of $1{ }^{\circ} \mathrm{C} / \mathrm{step}$ ), $5^{\prime \prime}$ (following steps); Cooling, $4{ }^{\circ} \mathrm{C}$ ). Thermal cycling and fluorescent detection were performed using the Rotor-Gene Q real-time PCR machine (model 2-Plex HRM) (Qiagen). The SYBR Green I reporter dye signal was measured. Resulting data were analyzed using the HMBS gene as an internal standard to normalize transcript levels. Cycle threshold (ct) values were calculated by the Rotor-Gene Q Software (version 2.0.2). All quantitative real-time PCR reactions were run in technical triplicates for each of the 3 patient and 2 control cell lines and mean ct-values for each reaction were taken into account for calculations.

\section{Protein biochemistry}

To obtain homogenate from cultures, cells were lysed and homogenized in lysis buffer $(150 \mathrm{mM} \mathrm{NaCl}, 1 \%$ Triton $\mathrm{X}-100,50 \mathrm{mM}$ Tris- $\mathrm{HCl}, \mathrm{pH}$ 8.0) containing protease inhibitor (Roche). Cell debris and nuclei were removed by centrifugation at $3200 \mathrm{rpm}$ for $10 \mathrm{~min}$. Protein concentration was determined by Bradford protein assay. Proteins were separated by SDS-PAGE and blotted onto nitrocellulose membranes (GE Healthcare). Immunoreactivity was visualized using HRP-conjugated secondary antibodies and the SuperSignal detection system (Pierce).
Statistic

Statistical analysis was performed with GraphPad Prism 7. Data are shown as mean \pm SEM. For comparisons, analysis of variance (ANOVA) was performed followed by post hoc tests for within group comparisons (Dunn's test, or Bonferroni test). For comparisons of two independent groups, student's $t$ tests was used. Statistically significant differences are indicated in the figures by $* p \leq 0.05, * * p \leq 0.01$ and $* * * p \leq 0.001$.

$q R T$ PCR quantification-Relative quantification is based on internal reference genes to determine virtual mRNA levels of target genes. Cycle threshold (ct) values were calculated by the Rotor-Gene Q Software (version 2.0.2). $\mathrm{Ct}$ values were transformed into virtual mRNA levels according to the formula: virtual $\mathrm{mRNA}$ level = $10 *\left(\left(\mathrm{ct}_{\text {(target) }}-\mathrm{ct}_{\text {(standart) }}\right) /\right.$ slope of standard curve $)$.

Western blot quantification-Evaluation of bands from Western blots (WBs) was performed using ImageJ. Three independent experiments were performed and blots imaged using a MicroChemi Imaging System from Biostep. The individual bands were selected and the integrated density was measured. All WB bands were normalized to $\beta$-Actin and the ratios averaged.

Immunocytochemistry-For cell culture experiments, 10 cells of each condition were imaged. The signal intensity of immuno-reactive signals was quantified using ImageJ software.

Acknowledgements AMG and AKS are supported by the Else Kröner-Fresenius Stiftung, and AMG by the JuniorprofessurenProgramm of the state of Baden Württemberg. SH is supported by the evangelisches Studienwerk Villigst e.V. SH is a member of the International Graduate School Molecular Medicine at Ulm University. The authors would like to thank Inga Wessels and Lothar Rink (University Hospital Aachen) for AAS measurements. The authors would like to acknowledge networking support by the COST Action TD1304..

\section{Compliance with ethical standards}

Conflict of interest The authors declare that there is no conflict of interests regarding the publication of this paper.

Open Access This article is distributed under the terms of the Creative Commons Attribution 4.0 International License (http:// creativecommons.org/licenses/by/4.0/), which permits unrestricted use, distribution, and reproduction in any medium, provided you give appropriate credit to the original author(s) and the source, provide a link to the Creative Commons license, and indicate if changes were made. 


\section{References}

Andrews GK (2008) Regulation and function of Zip4, the acrodermatitis enteropathica gene. Biochem Soc Trans 36(Pt 6): 1242-1246

Argiratos V, Samman S (1994) The effect of calcium carbonate and calcium citrate on the absorption of zinc in healthy female subjects. Eur J Clin Nutr 48(3):198-204

Brown KH, Peerson JM, Allen LH (1998) Effect of zinc supplementation on children's growth: a meta-analysis of intervention trials. Bibl Nutr Dieta 54:76-83

Burdette SC, Walkup GK, Spingler B, Tsien RY, Lippard SJ (2001) Fluorescent sensors for $\mathrm{Zn}(2+)$ based on a fluorescein platform: synthesis, properties and intracellular distribution. J Am Chem Soc 123(32):7831-7841

Chakrabarti AC (1994) Permeability of membranes to amino acids and modified amino acids: mechanisms involved in translocation. Amino Acids 6(3):213-229

Corti G, Maestrelli F, Cirri M, Zerrouk N, Mura P (2006) Development and evaluation of an in vitro method for prediction of human drug absorption II. Demonstration of the method suitability. Eur J Pharm Sci 27(4):354-362

Cousins RJ (2010) Gastrointestinal factors influencing zinc absorption and homeostasis. Int J Vitam Nutr Res 80(4-5):243-248

Cousins RJ, McMahon RJ (2000) Integrative aspects of zinc transporters. J Nutr 130(5):1384-1387

Dufner-Beattie J, Wang F, Kuo YM, Gitschier J, Eide D, Andrews GK (2003) The acrodermatitis enteropathica gene ZIP4 encodes a tissue-specific, zinc-regulated zinc transporter in mice. J Biol Chem 278(35):33474-33481

Fischer Walker C, Kordas K, Stoltzfus RJ, Black RE (2005) Interactive effects of iron and zinc on biochemical and functional outcomes in supplementation trials. Am J Clin Nutr 82(1):5-12

Furia TE (1975) Sequestrants in foods. In: Furia TE (ed) Handbook of food additives, 2nd edn. CRC Press, Boca Raton, pp 271-294

Gallaher DD, Johnson PE, Hunt JR, Lykken GI, Marchello MJ (1998) Bioavailability in humans of zinc from beef: intrinsic vs extrinsic labels. Am J Clin Nutr 48(2):350-354

Gao S, Yin T, Xu B, Ma Y, Hu M (2014) Amino acid facilitates absorption of copper in the Caco-2 cell culture model. Life Sci 109(1):50-56

Ghishan FK, Said HM, Wilson PC, Murrell JE, Greene HL (1986) Intestinal transport of zinc and folic acid: a mutual inhibitory effect. Am J Clin Nutr 43(2):258-262

Goldenberg RL, Tamura T, Neggers Y, Copper RL, Johnston KE, DuBard MB, Hauth JC (1995) The effect of zinc supplementation on pregnancy outcome. JAMA 274(6):463-468

Grabrucker AM (2014) A role for synaptic zinc in ProSAP/ Shank PSD scaffold malformation in autism spectrum disorders. Dev Neurobiol 74(2):136-146

Grabrucker S, Jannetti L, Eckert M, Gaub S, Chhabra R, Pfaender S, Mangus K, Reddy PP, Rankovic V, Schmeisser MJ, Kreutz MR, Ehret G, Boeckers TM, Grabrucker AM (2014) Zinc deficiency dysregulates the synaptic ProSAP/ Shank scaffold and might contribute to autism spectrum disorders. Brain 137(Pt 1):137-152
Grabrucker S, Boeckers TM, Grabrucker AM (2016) Gender dependent evaluation of autism like behavior in mice exposed to prenatal zinc deficiency. Front Behav Neurosci 10:37

Hall AC, Young BW, Bremner I (1979) Intestinal metallothionein and the mutual antagonism between copper and zinc in the rat. J Inorg Biochem 11(1):57-66

Hambidge KM, Krebs NF, Jacobs MA, Favier A, Guyette L, Ikle DN (1983) Zinc nutritional status during pregnancy: a longitudinal study. Am J Clin Nutr 37(3):429-442

Hambidge KM, Casey CE, Krebs NF (1986) Zinc. In: Mertz W (ed) Trace elements in human and animal nutrition, 5th edn, vol 2. Academic Press, Orlando, pp 1-137

Hill CH, Matrone G (1970) Chemical parameters in the study of in vivo and in vitro interactions of transition elements. Fed Proc 29(4):1474-1481

Huster D (2010) Wilson disease. Best Pract Res Clin Gastroenterol 24(5):531-539

Iwao T, Toyota M, Miyagawa Y, Okita H, Kiyokawa N, Akutsu H, Umezawa A, Nagata K, Matsunaga T (2014) Differentiation of human induced pluripotent stem cells into functional enterocyte-like cells using a simple method. Drug Metab Pharmacokin 29(1):44-51

King JC (2007) Determinants of maternal zinc status during pregnancy. Am J Clin Nutr 71(5 Suppl):1334-1343

Krebs NF (2000) Overview of zinc absorption and excretion in the human gastrointestinal tract. J Nutr 130(5S Suppl):13741377

Krebs NF, Westcott JE, Huffer JW, Miller LV (1998) Absorption of exogenous zinc and secretion of endogenous zinc in the human small intestine. FASEB J 12:A345

Lee HH, Prasad AS, Brewer GJ, Owyang C (1989) Zinc absorption in human small intestine. Am J Physiol 256(1 Pt 1):G87-91

Linta L, Stockmann M, Kleinhans KN, Böckers A et al (2012) Rat embryonic fibroblasts improve reprogramming of human keratinocytes into induced pluripotent stem cells. Stem Cells Dev 21(6):965-976

Lönnerdal B (2000) Dietary factors influencing zinc absorption. J Nutr 130(5S Suppl):1378-1383

Lönnerdal B, Keen CL, Hurley LS (1984) Zinc binding ligands and complexes in zinc metabolism. Adv Nutr Res 6:139-167

Lönnerdal B, Bell JG, Hendrick AG, Burns RA, Keen CL (1988) Effect of phytate removal on zinc absorption from soy formula. Am J Clin Nutr 48(5):1301-1306

Metzler-Zebeli BU, Caine WR, McFall M, Miller B, Ward TL, Kirkwood RN, Mosenthin R (2010) Supplementation of diets for lactating sows with zinc amino acid complex and gastric nutriment-intubation of suckling pigs with zinc methionine on mineral status, intestinal morphology and bacterial translocation in lipopolysaccharide-challenged weaned pigs. J Anim Physiol Anim Nutr 94:237-249

Mills CF (1985) Dietary interactions involving the trace elements. Annu Rev Nutr 5:173-193

Nayeri A, Upah NC, Sucu E, Sanz-Fernandez MV, DeFrain JM, Gorden PJ, Baumgard LH (2014) Effect of the ratio of zinc amino acid complex to zinc sulfate on the performance of Holstein cows. J Dairy Sci 97(7):4392-4404

O’Dell BL (1969) Effect of dietary components upon zinc bioavailability. Am J Clin Nutr 22:1315-1322 
O'Brien KO, Zavaleta N, Caulfield LE, Wen J, Abrams SA (2000) Prenatal iron supplements impair zinc absorption in pregnant Peruvian women. J Nutr 130(9):2251-2255

Osorio JS, Trevisi E, Li C, Drackley JK, Socha MT, Loor JJ (2016) Supplementing $\mathrm{Zn}, \mathrm{Mn}$, and $\mathrm{Cu}$ from amino acid complexes and Co from cobalt glucoheptonate during the peripartal period benefits postpartal cow performance and blood neutrophil function. J Dairy Sci 99(3):1868-1883

Payne RL, Bidner TD, Fakler TM, Southern LL (2006) Growth and intestinal morphology of pigs from sows fed two zinc sources during gestation and lactation. J Anim Sci 84(8):2141-2149

Pfaender S, Grabrucker AM (2014) Characterization of biometal profiles in neurological disorders. Metallomics 6(5):960-977

Prasad AS (2014) Impact of the discovery of human zinc deficiency on health. J Trace Elem Med Biol 28(4):357-363

Raghavan R, Fallin MD, Wang X (2016) Maternal plasma folate, vitamin B12 levels and multivitamin supplementation during pregnancy and risk of Autism Spectrum Disorder in the Boston Birth Cohort. FASEB J 30 (1 Suppl):151.6

Sandström B (1992) Dose dependence of zinc and manganese absorption in man. Proc Nutr Soc 51(2):211-218

Sandström B, Cederblad A (1980) Zinc absorption from composite meals. II. Influence of the main protein source. Am J Clin Nutr 33(8):1778-1783
Shankar AH, Prasad AS (1998) Zinc and immune function: the biological basis of altered resistance to infection. Am J Clin Nutr 68(2 Suppl):447-463

Simmer K, Iles CA, James C, Thompson RP (1987) Are ironfolate supplements harmful? Am J Clin Nutr 45(1):122-125

Star L, van der Klis JD, Rapp C, Ward TL (2012) Bioavailability of organic and inorganic zinc sources in male broilers. Poult Sci 91(12):3115-3120

Vohra P, Kratzer FH (1964) Influence of various chelating agents on the availability of zinc. J Nutr 82:249-256

Warlich E, Kuehle J, Cantz T, Brugman MH (2011) Lentiviral vector design and imaging approaches to visualize the early stages of cellular reprogramming. Mol Ther 19(4):782-789

Whiting SJ, Wood RJ (1997) Adverse effects of high-calcium diets in humans. Nutr Rev 55(1 Pt1):1-9

Wood RJ, Zheng JJ (1997) High dietary calcium intakes reduce zinc absorption and balance in humans. Am J Clin Nutr 65(6):1803-1809

Zödl B, Zeiner M, Sargazi M, Roberts NB, Marktl W, Steffan I, Ekmekcioglu C (2003) Toxic and biochemical effects of zinc in Caco-2 cells. J Inorg Biochem 97(4):324-330 